\title{
RP-HPLC METHOD FOR SIMULTANEOUS ESTIMATION OF RITONAVIR, OMBITASVIR AND PARITAPREVIR IN TABLET DOSAGE FORMS AND THEIR STRESS DEGRADATION STUDIES
}

\author{
SYED IBRAHIM BAJE ${ }^{1}$, B. JYOTHI ${ }^{2}$, N. MADHAVI ${ }^{3 *}$
}

1,3PG Department of Chemistry, JKC College, Acharya Nagarjuna University, Guntur, A. P., ${ }^{2}$ Department of Chemistry, Swarna Bharathi Institute of Science and Technology, Khammam, Telangana

Email: madhavijkcchempg@gmail.com

Received: 26 Jun 2018, Revised and Accepted: 30 Jan 2019

\section{ABSTRACT}

Objective: The objective of the present study was to develop and validate a novel reverse phase high performance liquid chromatographic (RPHPLC) method, for simultaneous determination of ritonavir (RIT), ombitasvir (OMB) and paritaprevir (PAR) in bulk mixtures, and in tablets.

Methods: Determination of the drugs ritonavir (RIT), ombitasvir (OMB), and paritaprevir (PAR), was carried out applying Hypersil BDS C18 column ( $250 \mathrm{~mm}$ X $4.6 \mathrm{~mm}$ i.e., $5 \mu \mathrm{m}$ particle size), with photodiode array detector at $\lambda_{\max }$ of $254 \mathrm{~nm}$. The mobile phase applied for the current study composed of two solvents, i.e. A $(0.01 \mathrm{~N} \% \mathrm{w} / \mathrm{v}$ potassium di-hydrogen orthophosphate buffer, $\mathrm{pH} 3.0$ adjusted with dilute orthophosphoric acid) and B (acetonitrile). The mobile phase was pumped at a flow rate of $1.0 \mathrm{ml} / \mathrm{min}$ in the isocratic mode. The validation study with respect to specificity, linearity, precision, accuracy, and robustness, limit of detection (LOD) and limit of quantification (LOQ) was carried out employing the ICH guidelines.

Results: Ritonavir, ombitasvir, and paritaprevir showed linearity of response between $12.5-75 \mu \mathrm{g} / \mathrm{ml}$ for ritonavir, 3.125-18.75 $\mu \mathrm{g} / \mathrm{ml}$ for ombitasvir and $18.75-112.5 \mu \mathrm{g} / \mathrm{ml}$ for paritaprevir, with a correlation coefficient $\left(\mathrm{R}^{2}\right)$ 0.999, 0.999,0.999 for RIT, OMB, and PAR respectively. The \% recovery obtained was $99.82 \pm 0.14 \%$ RIT, OMB $100.03 \pm 0.96 \%$ and for $99.96 \pm 0.26 \%$ PAR. The LOD and LOQ values for RIT, OMB, PAR were obtained to be $0.02,0.019$ and $0.02, \mu \mathrm{g} / \mathrm{ml}$ and $0.07,0.06$ and $0.07 \mu \mathrm{g} / \mathrm{ml}$, respectively. The method also exhibits good robustness for different chromatographic conditions like wavelength, flow rate, mobile phase, and injection volume.

Conclusion: The method was successfully employed, for the quantification of RIT, OMB, and PAR, in the quality control of in-house developed tablets, and can be applied for the industrial use.

Keywords: Ombitasvir, Ritonavir, Paritaprevir, RP-HPLC, ICH guidelines

(c) 2019 The Authors. Published by Innovare Academic Sciences Pvt Ltd. This is an open access article under the CC BY license (http://creativecommons.org/licenses/by/4.0/) DOI: http://dx.doi.org/10.22159/ijap.2019v11i2.28141

\section{INTRODUCTION}

Ritonavir, [1] is chemically known as 2,4,7,12-tetra azatridecan-13oicacid, 10-hydroxy-2-methyl-5-(1-methyl ethyl)-1-[2-(1-methyl ethyl)4-thiazolyl]-3,6-dioxo-8,11-bis(phenylmethyl)-5-thiazolmethyl ester. It is an antiretroviral drug [2], an inhibitor of HIV-1 (human immunodeficiency virus) protease [3-5] used to treat HIV infection and AIDS (acquired immune deficiency syndrome). As of now once in a while utilized for its own particular antiviral movement [6], yet remains generally utilized as a sponsor of other protease inhibitors. This prevents cleavage of the gag-pol polyprotein [7]. All the more particularly, ritonavir is utilized to restrain a specific liver catalyst that ordinarily processes protease inhibitors, CYP3A4 is a member of the cytochrome P450 family of oxidizing enzymes [8]. Ombitasvir is an antiviral medication for the treatment of hepatitis C [9] infection (HCV) due to hepatitis C virus. In the United States, it is affirmed by the Food and Drug Administration for use in the blend with paritaprevir, ritonavir and dasabuvir in Viekira Pak for the treatment of HCV genotype $1[10]$ and with paritaprevir and ritonavir in Technivie for the treatment of HCV genotype 4 [11]. Paritaprevir is an acyl sulfonamide inhibitor that shows promising outcomes for the treatment of hepatitis $C$ [12]. At the point when given in mix with ritonavir and ribavirin for $12 \mathrm{w}$, the rate of supported virological reaction at $24 \mathrm{w}$ after treatment has been evaluated to be $95 \%$ for those with hepatitis $\mathrm{C}$ virus genotype 1 [13]. Resistance to treatment with paritaprevir is phenomenal, on the grounds that it focuses on the coupling site, however, has been believed to emerge because of transformations at positions 155 and 168 in NS3 [14]. Paritaprevir is available in three fixed-dose products: Viekira Pak (FDA), Technivie (FDA and Health Canada) and Holkira Pak (Health Canada) in Canada and the United States [15]. Different analytical methods are in like manner itemized in the written work for the estimation of ritonavir, ombitasvir and paritaprevir. As showed by composing study there is one specialized method for the estimation of ritonavir, ombitasvir and paritaprevir by RP-HPLC in tablet estimation $[16,17]$. Thus, it has been proposed to make a method for estimation and endorsement of ritonavir, ombitasvir and paritaprevir in the arrangement according to the ICH rules [18].

\section{MATERIALS AND METHODS}

\section{Instrumentation}

Chromatography was performed with Alliance waters 2695 HPLC, autosampler, section stove, degasser, 2996 PDA locator and class empower-2 software.

\section{Reagents and chemicals}

Acetonitrile (HPLC grade), orthophosphoric acid (HPLC grade) and water (HPLC grade) were purchased from Merck (India) Ltd, Worli, Mumbai, India. All active pharmaceutical ingredients (APIs) of ritonavir, ombitasvir, and paritaprevir as reference standards were procured from Spectrum Pharma labs, Hyderabad, India.

\section{Chromatographic condition}

Chromatographic analysis was done using isocratic elution and by using acetonitrile and $0.01 \mathrm{~N}$ potassium di-hydrogen phosphate, $\mathrm{pH}$ adjusted to 3.0 with OPA ( $65: 35$ by volume) as a mobile phase and was filtered through $0.45 \mu$ membrane filter paper. The flow rate of mobile phase was monitored at $1 \mathrm{ml} / \mathrm{min}$ and eluents were detected at 254 $\mathrm{nm}$. Operating pressure $2400 \mathrm{psi}$ was maintained at room temperature by injecting the volume $10 \mu \mathrm{l}$ with a runtime $7 \mathrm{~min}$.

\section{Preparation of standard solution}

Accurately weighed $50 \mathrm{mg}$ of ritonavir, $12.5 \mathrm{mg}$ of ombitasvir and 75 $\mathrm{mg}$ of paritaprevir were taken and exchanged to three $100 \mathrm{ml}$ volumetric flasks independently. $10 \mathrm{ml}$ of methanol was added to flagons and sonicated for $15 \mathrm{~min}$ and then diluted to $1 \mathrm{ml}$ of the above solution to $10 \mathrm{ml}$ with the diluent.

\section{Preparation of sample solution}

5 tablets were weighed and calculated the average weight of each tablet. Then the weight equivalent to 1 tablet was transferred into a $100 \mathrm{ml}$ volumetric flask, $30 \mathrm{ml}$ of diluent added and sonicated for 25 
min, further, the volume made up with diluent and filtered. $1 \mathrm{ml}$ of filtered sample stock solution was transferred to the $10 \mathrm{ml}$ volumetric flask and made up with diluents.

\section{Validation}

The optimized chromatographic separation was aimed to obtain a resolution above 6.3 between all components, tailing factor is less than 2.0 and plate count will be more than 2000 with respect to the stationary, mobile phase compositions, flow rate, sample volume, detection wavelength and temperature.

\section{Validation procedure}

In the present method, validation was done with the aspect of system suitability, specificity, accuracy, precision, linearity, robustness, limit of detection (LOD), limit of quantitation (LOQ), forced degradation and stability according to the ICH guidelines $[19,20]$.

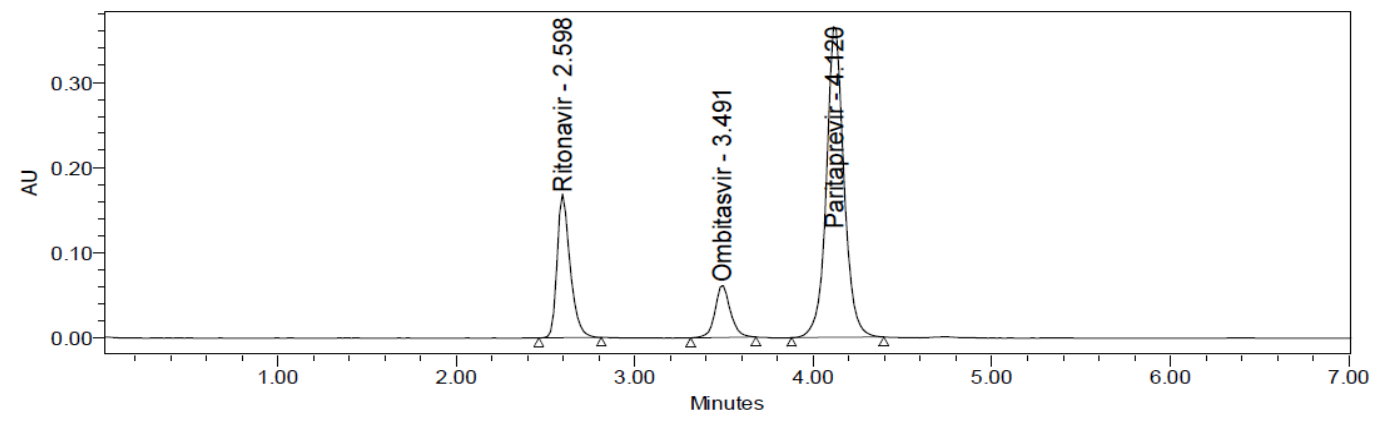

Fig. 1: Typical chromatogram for ritonavir, ombitasvir and paritaprevir

\section{System suitability}

As per the test method, the standard solutions were prepared and injected into HPLC system, from which the evaluated system suitability parameters were found to be within the limits [21,22].

\section{Specificity}

The analyte was assessed unequivocally to know the components impurity which may be expected to be present with the help of specificity. As per test method blank was prepared and injected. No blank peak was eluted in the retention time of the analyte peak. Placebo solutions were prepared in duplicate and injected as per test method. It was found that no placebo peaks interfered at the retention time of the main peak [23].

\section{Accuracy}

Three different concentrations such as lower quantitation limit, medium quantitation limit, and higher quantitation limit were used to evaluate the accuracy of RP-HPLC method. The amount of drugs present, percentage recovery, and RSD were calculated by giving a minimum of three injections from each concentration.

\section{Precision}

The precision of test method was evaluated by considering six different concentrations. The amount of drugs present, percentage recovery, and RSD were calculated by giving a minimum of six preparations.

\section{Linearity and range}

Six series of standard solutions were selected for assessing linearity range, by using peak area versus concentration of the standard solution. Calibration curve was plotted and the regression equations were also calculated. The slope, intercept and correlation coefficient were calculated by the least squares method.

\section{LOD and LOQ}

By using optimized chromatographic conditions in accordance with $3.3 \mathrm{~s} / \mathrm{n}$ and $10 \mathrm{~s} / \mathrm{n}$ criteria, where $\mathrm{s} / \mathrm{n}$ indicates signal-to-noise ratio, the LOD and LOQ were determined by injecting progressively lower concentrations of standard solutions into the HPLC column.

\section{Forced degradation}

In chromatogram of forced degradation there should be no interference between peaks and were well separated from each other with the resolution at least 1.0 and peak purity of the principal peaks should pass. Forced degradation studies were performed by different types of stress conditions to obtain the degradation of about $20 \%$.

\section{Robustness}

Small changes such as $\pm 10 \%$ in the ratio of acetonitrile in the mobile phase, $\pm 0.1 \mathrm{ml} / \mathrm{min}$ in the flow rate and $\pm 5{ }^{\circ} \mathrm{C}$ in the temperature were made to demonstrate the robustness method. The separation factor, retention time and peak asymmetry were calculated.

\section{Stability}

Standard and the sample solutions were subjected to $24 \mathrm{~h}$ stability studies. The stability of these solutions was studied and observed for changes in the area and retention time of the peaks which were then compared with pattern of chromatogram of freshly prepared solution.

\section{Statistical analysis}

Wherever applicable, results were expressed as the mean \pm SD, \% RSD and data were analyzed statistically by using t-test with aid of Microsoft Excel-2007 software and data was considered not significantly different at $5 \%$ significance level of probability P $\leq 0.05$.

\section{RESULTS AND DISCUSSION}

\section{Method development}

Initially, reverse phase liquid chromatography separation was tried to develop using various ratios of methanol and water, acetonitrile and water as mobile phases, in which drugs did not respond properly, and the resolution was also poor. The organic content of the mobile phase was also investigated to optimize the separation of both drugs. To improve the tailing factor, the $\mathrm{pH}$ of mobile phase becomes an important factor. Hypersil BDS $250 \mathrm{~mm} \times 4.6 \mathrm{~mm}$, i.e. $5 \mu \mathrm{m} \square$ with an isocratic mobile phase composed of $0.01 \mathrm{~N} \mathrm{KH}_{2} \mathrm{PO}_{4}$ buffer and acetonitrile (65:35A) at a flow rate of $1 \mathrm{ml} / \mathrm{min}$. The column temperature was maintained at $30{ }^{\circ} \mathrm{C}$ and the detection was carried out using a PDA detector at $254 \mathrm{~nm}$. The tailing of both peaks was reduced considerably and brought close to 1 . Drug detections were tried at wavelength $254 \mathrm{~nm}$. Ritonavir, ombitasvir and paritaprevir showed maximum absorption at $254 \mathrm{~nm}$ of wavelength and $254 \mathrm{~nm}$ was selected as the detection wavelength for PDA detector. The retention times were found to about $2.598 \mathrm{~min}, 3.491 \mathrm{~min}$ and $4.120 \mathrm{~min}$ for ritonavir, ombitasvir and paritaprevir. The chromatogram obtained was shown in the fig. 1

\section{Method validation}

\section{System suitability and Specificity}

$10 \mu \mathrm{l}$ of working standard solution (ritonavir $50 \mu \mathrm{g} / \mathrm{ml}$, ombitasvir $12.5 \mu \mathrm{g} / \mathrm{ml}$ and paritaprevir $75 \mu \mathrm{g} / \mathrm{ml}$ ) was prepared and injected into the system. It was determined by making six replicate injections and all the parameters were found to be within the limits. The results were given in table 1 . 
Table 1: System suitability parameters for ritonavir, ombitasvir and paritaprevir

\begin{tabular}{|c|c|c|c|c|c|c|c|c|c|}
\hline S. No. & Ritonavir & & & Ombitas & & & Paritapr & & \\
\hline Inj & Rt(min) & Tp & Tailing & Rt(min) & Tp & Tailing & Rt(min) & Tp & Tailing \\
\hline 1 & 2.568 & 6022 & 1.32 & 3.484 & 8244 & 1.11 & 4.104 & 8981 & 1.06 \\
\hline 2 & 2.571 & 6105 & 1.32 & 3.484 & 8272 & 1.09 & 4.106 & 9054 & 1.06 \\
\hline 3 & 2.574 & 6272 & 1.32 & 3.485 & 8284 & 1.09 & 4.107 & 9075 & 1.06 \\
\hline 4 & 2.581 & 6059 & 1.33 & 3.486 & 8706 & 1.09 & 4.111 & 9280 & 1.06 \\
\hline 5 & 2.588 & 6226 & 1.33 & 3.491 & 8432 & 1.05 & 4.117 & 9024 & 1.06 \\
\hline 6 & 2.598 & 5995 & 1.32 & 3.491 & 8461 & 1.1 & 4.12 & 8911 & 1.05 \\
\hline
\end{tabular}

\section{Linearity}

The calibration curve was linear in the range of $12.5-75 \mu \mathrm{g} / \mathrm{ml}$ for ritonavir, $3.125-18.75 \mu \mathrm{g} / \mathrm{ml}$ for ombitasvir and $18.75-112.5 \mu \mathrm{g} / \mathrm{ml}$ for paritaprevir. These were represented in linear regression equation by as follows: $\mathrm{y}=16942 . \mathrm{x}+543.0\left(\mathrm{R}^{2}=0.999\right)$ for ritonavir, $y=29239 . x+581.5\left(R_{2}=0.999\right)$ for ombitasvir $y=33194 . x+605.2$ $\mathrm{R}_{2}=0.999$ ) for paritaprevir and a regression line was established by the least squares method and correlation coefficient $\left(\mathrm{R}^{2}\right)$ for ritonavir, ombitasvir, and paritaprevir was found to be greater than 0.98 Hence the curves established were linear. The results were given in table 2.

Table 2: Linearity data for ritonavir, ombitasvir and paritaprevir

\begin{tabular}{|c|c|c|c|c|c|}
\hline Ritonavir & & Ombitasvir & & Paritaprevir & \\
\hline Conc $(\mu \mathrm{g} / \mathrm{ml})$ & Peak area & Conc $(\mu \mathrm{g} / \mathrm{ml})$ & Peak area & Conc $(\mu \mathrm{g} / \mathrm{ml})$ & Peak area \\
\hline 12.5 & 207143 & 3.125 & 93230 & 18.75 & 621771 \\
\hline 25 & 434680 & 6.25 & 185929 & 37.5 & 1252558 \\
\hline 37.5 & 632715 & 9.375 & 269148 & 56.25 & 1865441 \\
\hline 50 & 849226 & 12.5 & 365988 & 75 & 2474466 \\
\hline 62.5 & 1052389 & 15.625 & 460995 & 93.75 & 3132183 \\
\hline 75 & 1274858 & 18.75 & 547621 & 112.5 & 3728106 \\
\hline Corr Coef & 0.999 & Corr Coef & 0.999 & Corr Coef & 0.999 \\
\hline Slope & 16942 & Slope & 29239 & Slope & 33194 \\
\hline Intercept ? & 543.0 & Intercept ? & 581.5 & Intercept ? & 605.2 \\
\hline
\end{tabular}

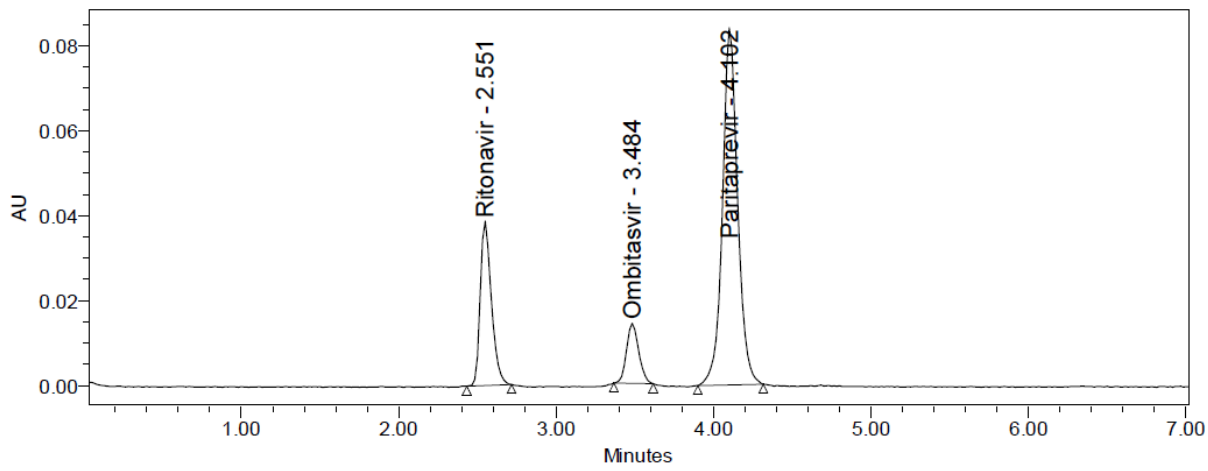

Fig. 2: Chromatogram for linearity-1

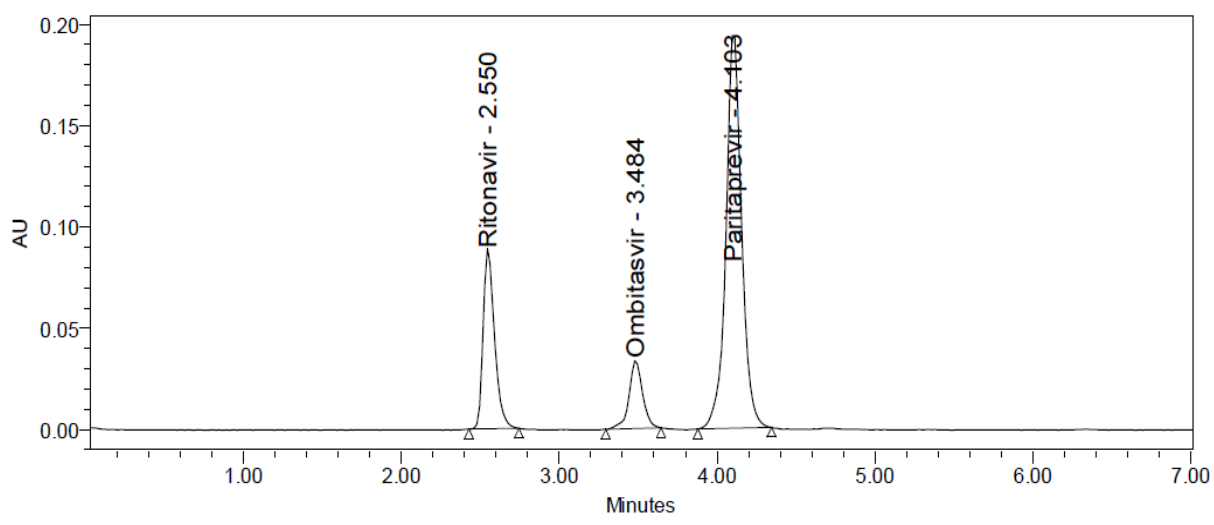

Fig. 3: Chromatogram for linearity-2 


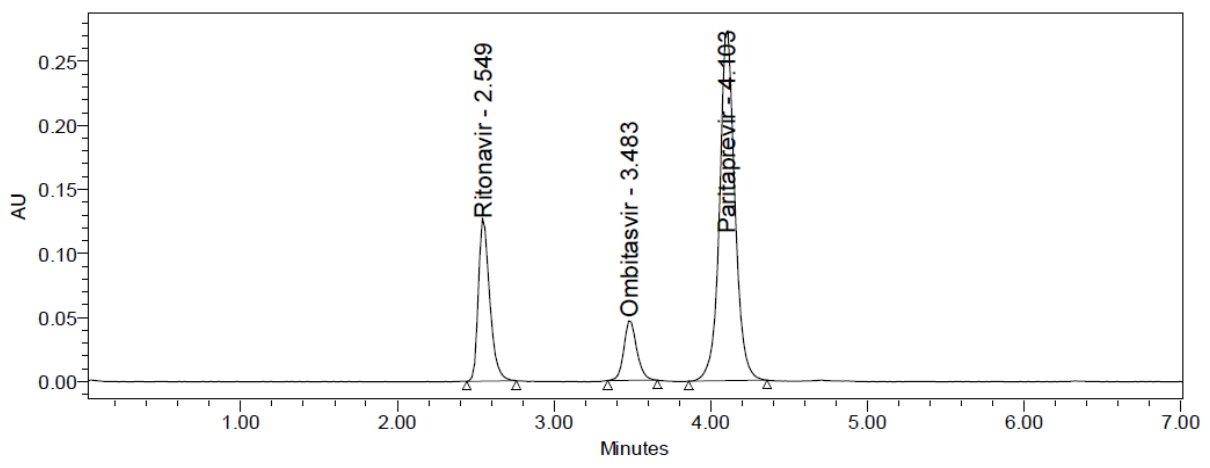

Fig. 4: Chromatogram for linearity-3

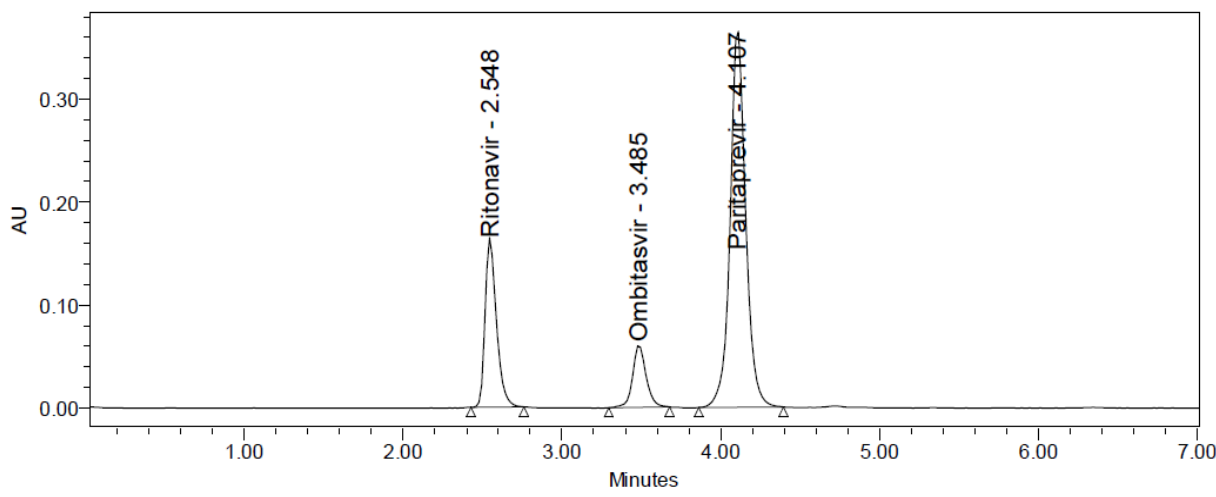

Fig. 5: Chromatogram for linearity-4

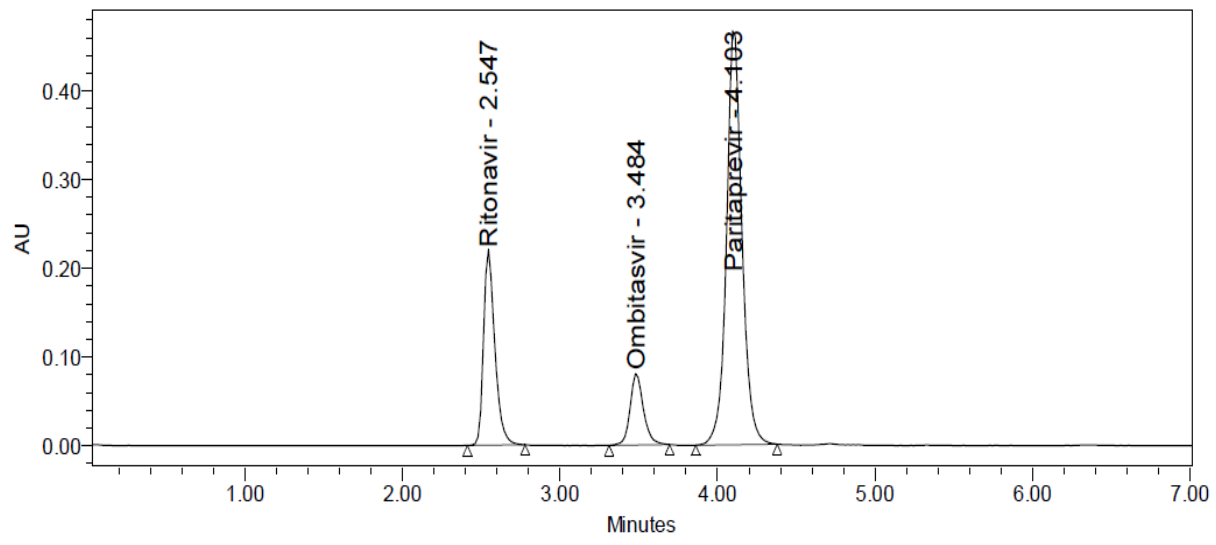

Fig. 6: Chromatogram for linearity-5

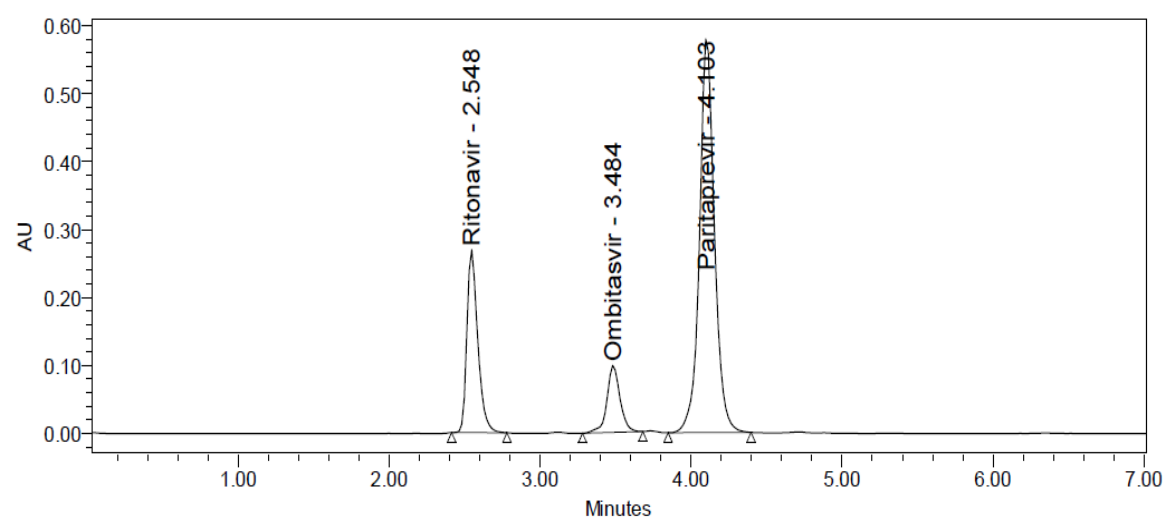

Fig. 7: Chromatogram for linearity-6 


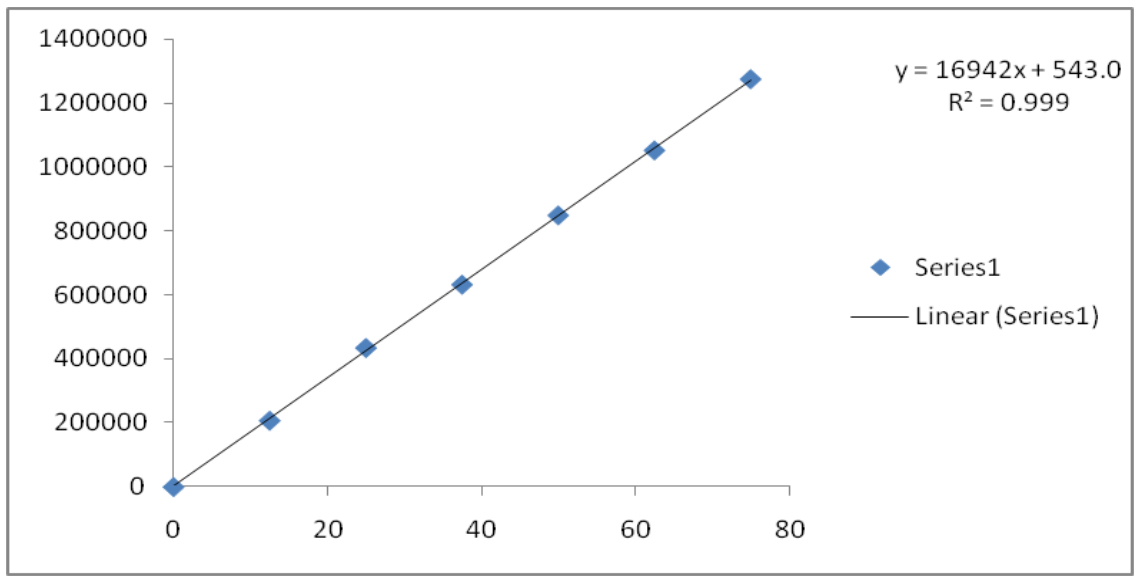

Fig. 8: Linearity plot for ritonavir

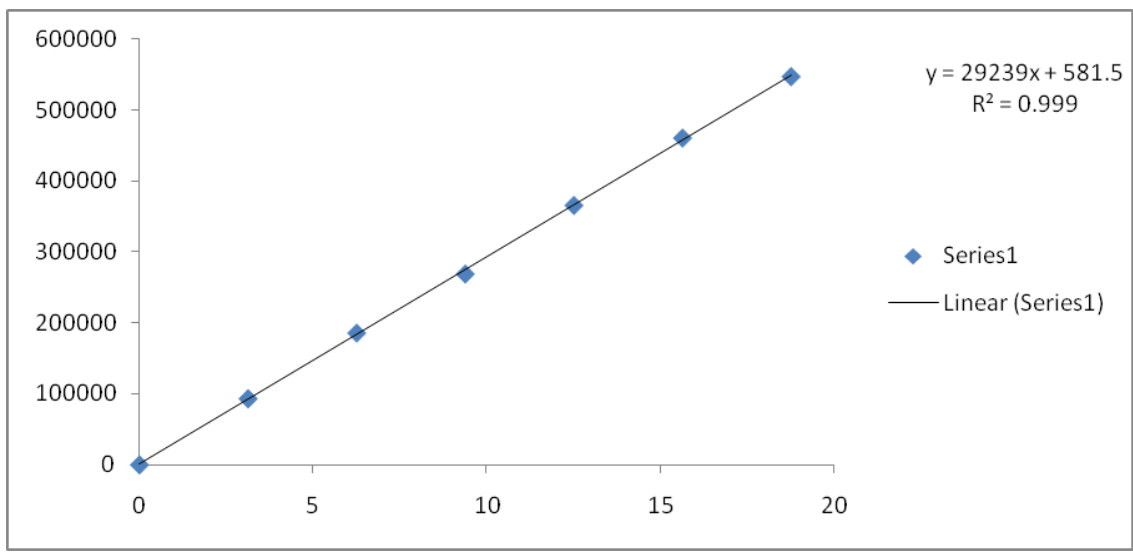

Fig. 9: Linearity plot for ombitasvir

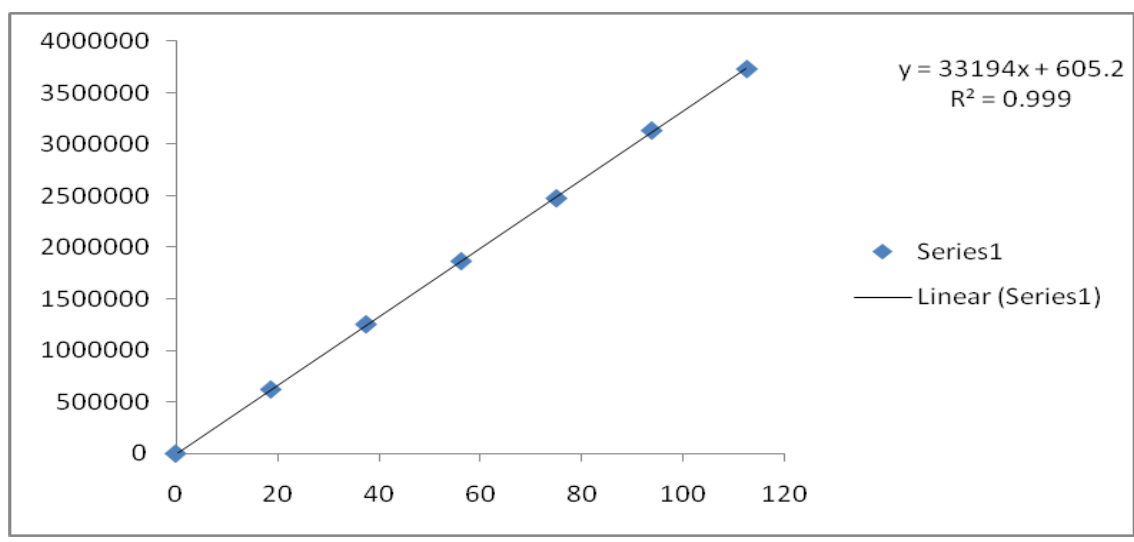

Fig. 10: Linearity plot for paritaprevir, $\mathrm{X}$-axis = concentration, $\mathrm{Y}$-axis = peak area

Table 3: Accuracy data for ritonavir

\begin{tabular}{llllll}
\hline \% Level & Amount spiked $(\boldsymbol{\mu g} / \mathbf{m l})$ & Amount recovered $(\boldsymbol{\mu g} / \mathbf{m l})$ & Area counts & \% Recovery & Mean \pm SD \\
\hline $50 \%$ & 25 & 24.78 & 1267509 & 99.13 & 99.72, \\
& 25 & 25.17 & 1274083 & 100.68 & 0.84 \\
$100 \%$ & 25 & 24.84 & 1268467 & 99.36 & \\
& 50 & 50.48 & 1702847 & 100.96 & 100.18, \\
& 50 & 49.85 & 1692222 & 99.70 & 0.68 \\
\\
$150 \%$ & 50 & 49.94 & 1693777 & 99.89 & \\
& 75 & 74.37 & 2107589 & 99.16 & 99.54, \\
& 75 & 74.71 & 2113333 & 99.61 & 0.36 \\
\hline
\end{tabular}

\#SD: Standard deviation, result expressed in mean \pm SD and $n=3$ 
Table 4: Accuracy data for ombitasvir

\begin{tabular}{|c|c|c|c|c|c|}
\hline \% Level & Amount spiked $(\mu \mathrm{g} / \mathrm{ml})$ & Amount recovered $(\mu \mathrm{g} / \mathrm{ml})$ & Area counts & \% Recovery & Mean \pm SD \\
\hline \multirow[t]{3}{*}{$50 \%$} & 6.25 & 6.273 & 549483 & 100.37 & 99.95, \\
\hline & 6.25 & 6.244 & 548638 & 99.90 & 0.39 \\
\hline & 6.25 & 6.224 & 548057 & 99.59 & \\
\hline \multirow[t]{3}{*}{$100 \%$} & 12.5 & 12.573 & 733683 & 100.58 & 100.33, \\
\hline & 12.5 & 12.606 & 734655 & 100.85 & 0.68 \\
\hline & 12.5 & 12.445 & 729940 & 99.56 & \\
\hline \multirow[t]{3}{*}{$150 \%$} & 18.75 & 18.807 & 915981 & 100.31 & 99.80, \\
\hline & 18.75 & 18.754 & 914411 & 100.02 & 0.64 \\
\hline & 18.75 & 18.579 & 909292 & 99.09 & \\
\hline
\end{tabular}

\#SD: Standard deviation, result expressed in mean \pm SD and $n=3$

Table 5: Accuracy data for paritaprevir

\begin{tabular}{|c|c|c|c|c|c|}
\hline \% Level & Amount spiked $(\mu \mathrm{g} / \mathrm{ml})$ & Amount recovered $(\mu \mathrm{g} / \mathrm{ml})$ & Area counts & \% Recovery & Mean \pm SD \\
\hline \multirow[t]{3}{*}{$50 \%$} & 37.5 & 37.92 & 3748935 & 101.13 & 100.06 \\
\hline & 37.5 & 37.36 & 3730192 & 99.62 & 0.92 \\
\hline & 37.5 & 37.29 & 3728023 & 99.45 & \\
\hline \multirow[t]{3}{*}{$100 \%$} & 75 & 74.84 & 4974242 & 99.78 & 100.15, \\
\hline & 75 & 75.16 & 4985115 & 100.22 & 0.34 \\
\hline & 75 & 75.34 & 4990947 & 100.45 & \\
\hline \multirow[t]{3}{*}{$150 \%$} & 112.5 & 111.57 & 6193620 & 99.17 & 99.66, \\
\hline & 112.5 & 112.74 & 6232462 & 100.21 & 0.52 \\
\hline & 112.5 & 112.05 & 6209539 & 99.60 & \\
\hline
\end{tabular}

"SD: Standard deviation, result expressed in mean \pm SD and $n=3$

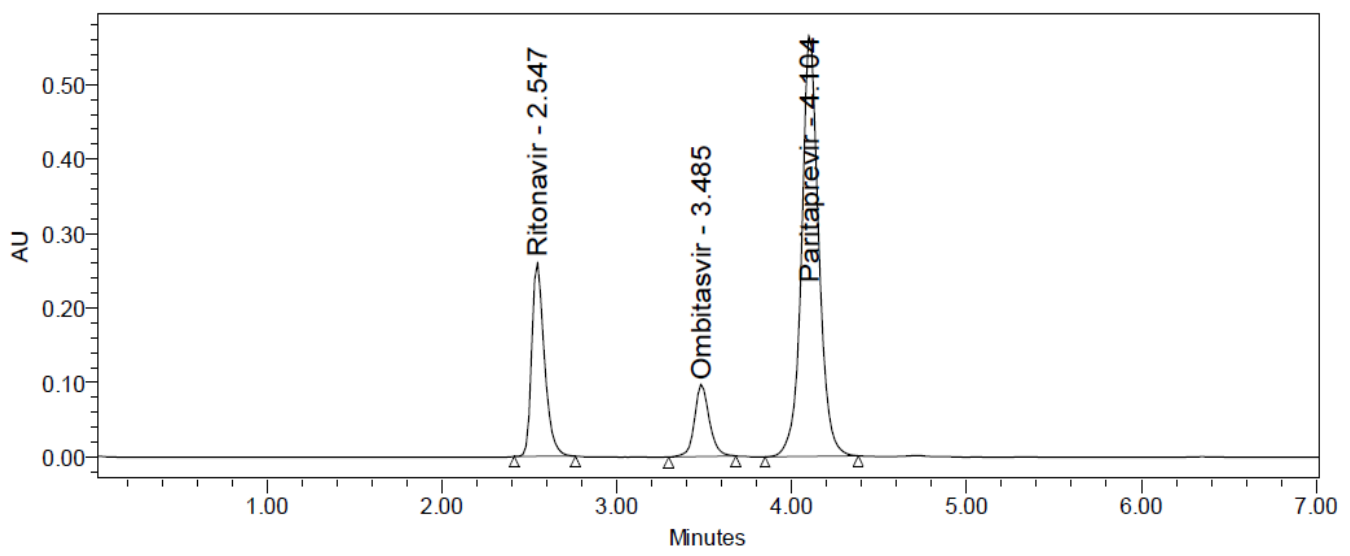

Fig. 11: Chromatogram for accuracy 50\%-1

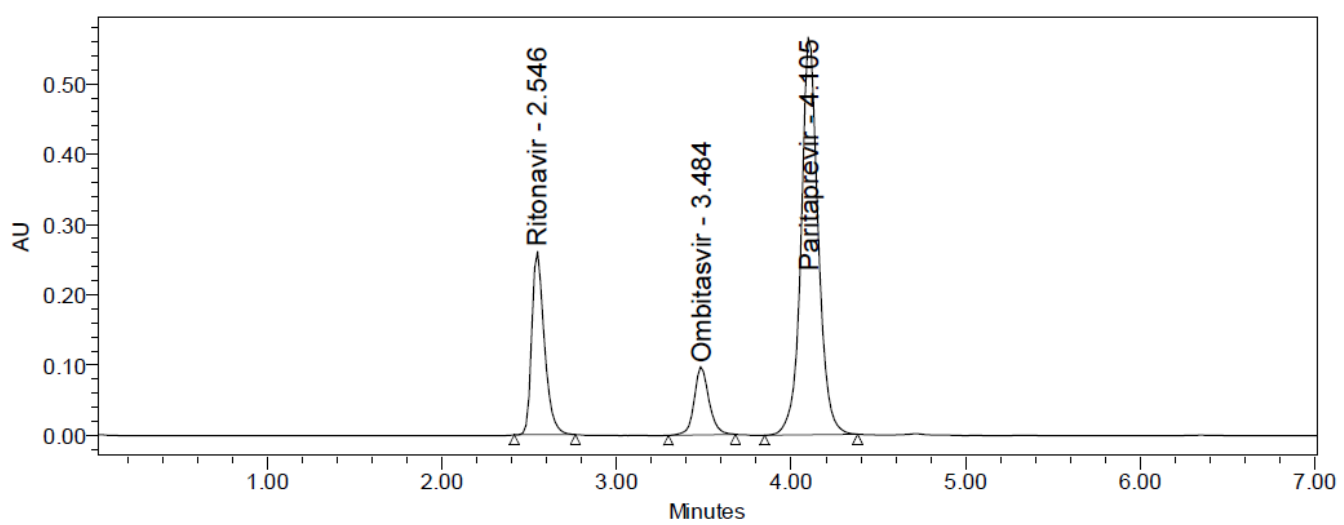

Fig. 12: Chromatogram for accuracy 50\%-2 


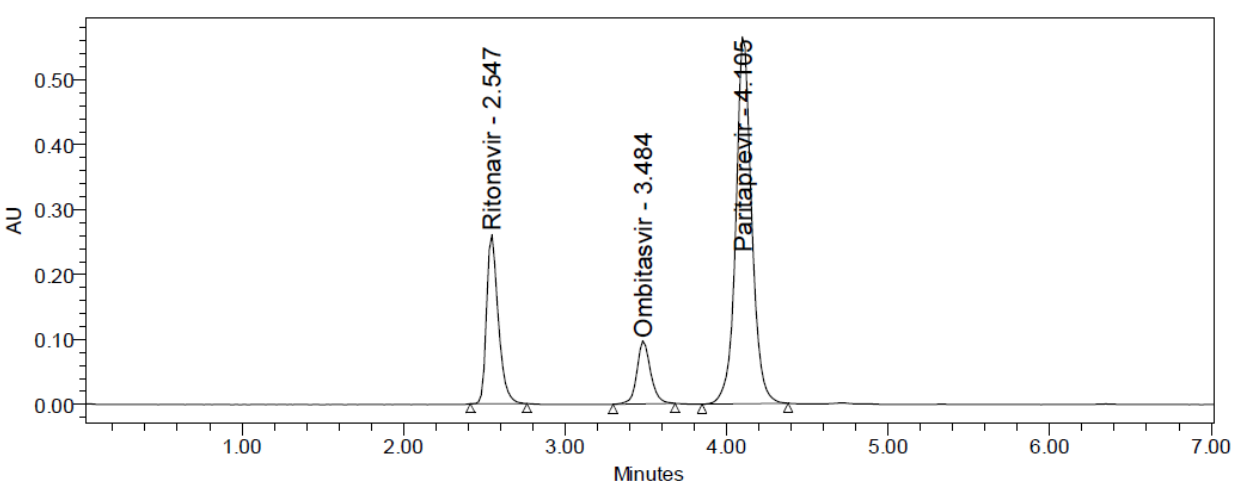

Fig. 13: Chromatogram for accuracy 50\%-3

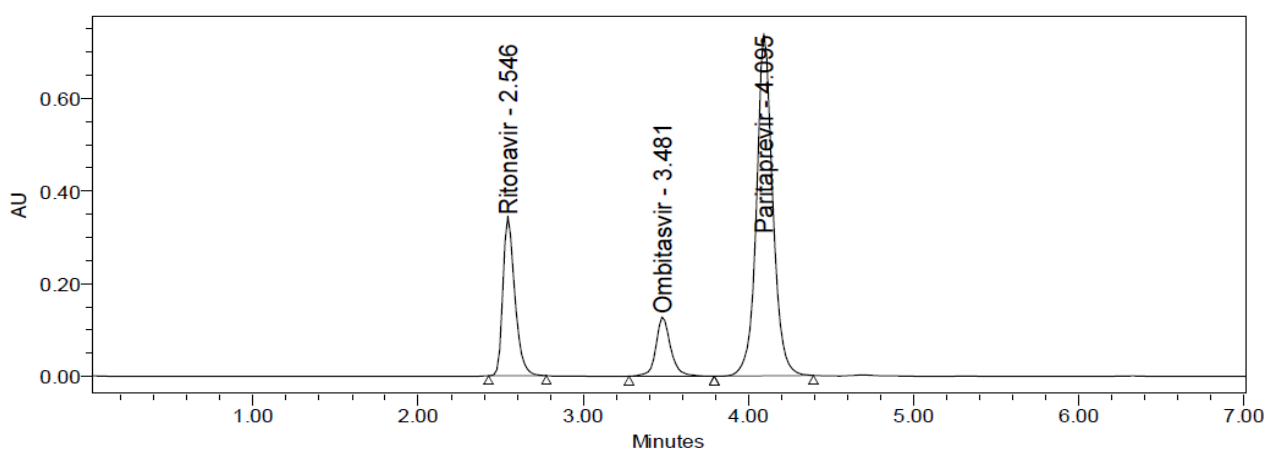

Fig. 14: Chromatogram for accuracy $100 \%-1$

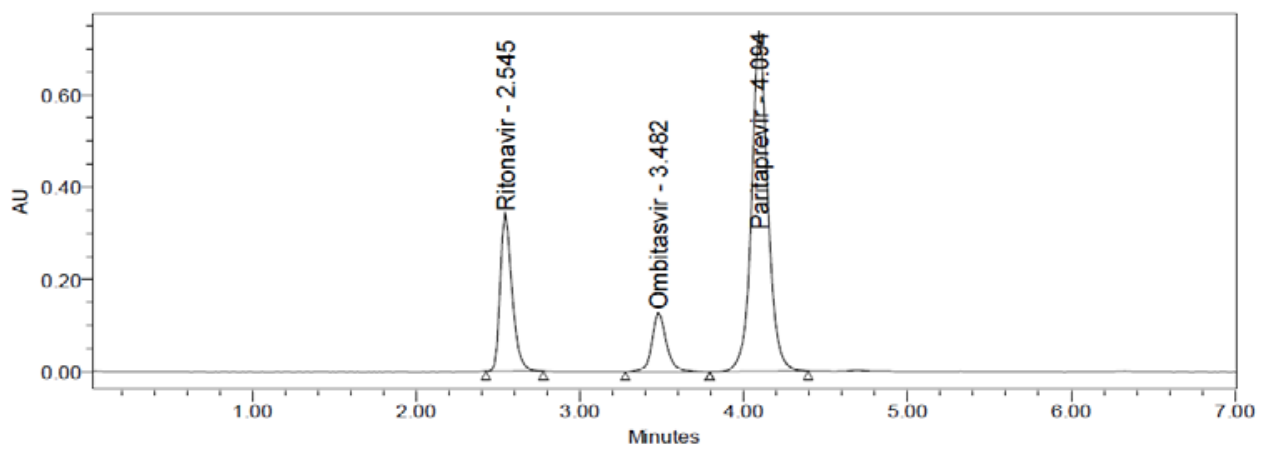

Fig. 15: Chromatogram for accuracy $100 \%-2$

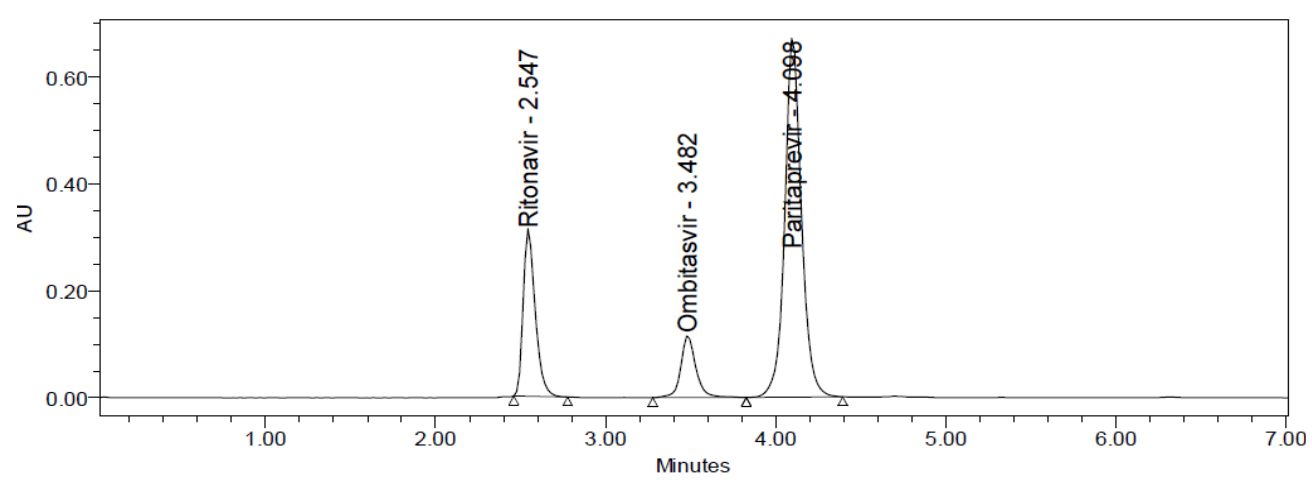

Fig. 16: Chromatogram for accuracy 100\%-3 


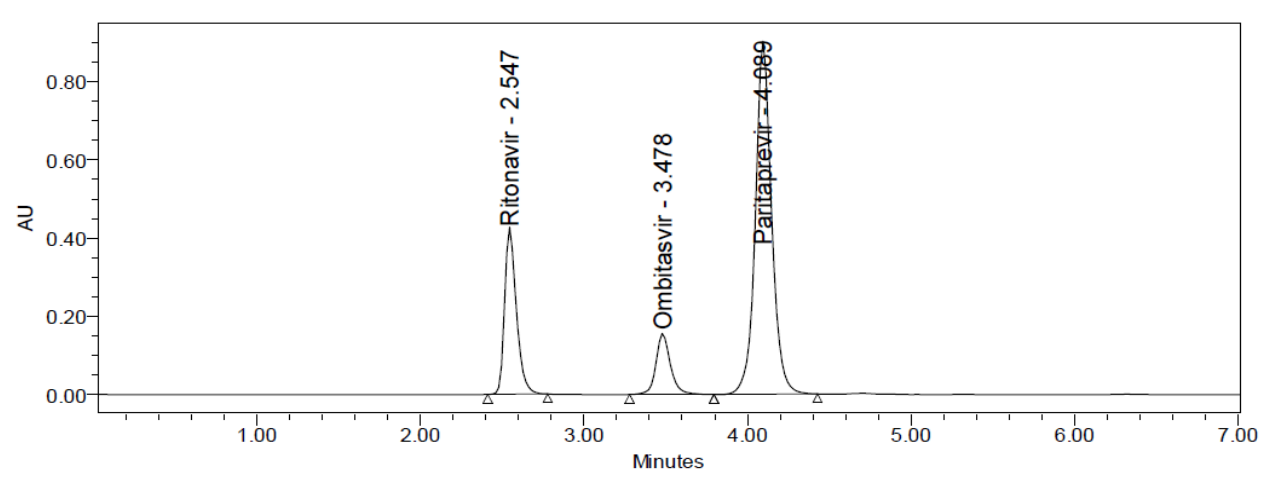

Fig. 17: Chromatogram for accuracy $150 \%-1$

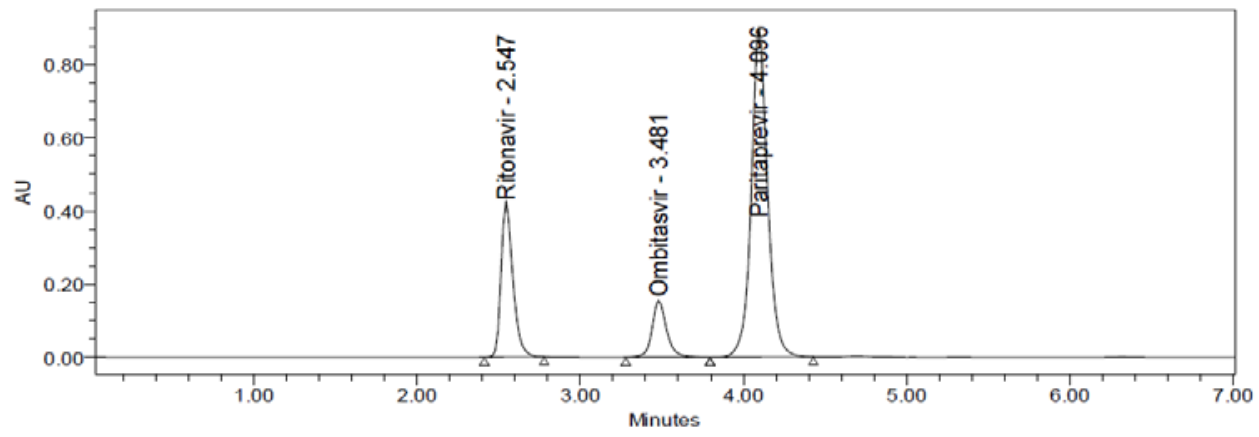

Fig. 18: Chromatogram for accuracy $150 \%-2$

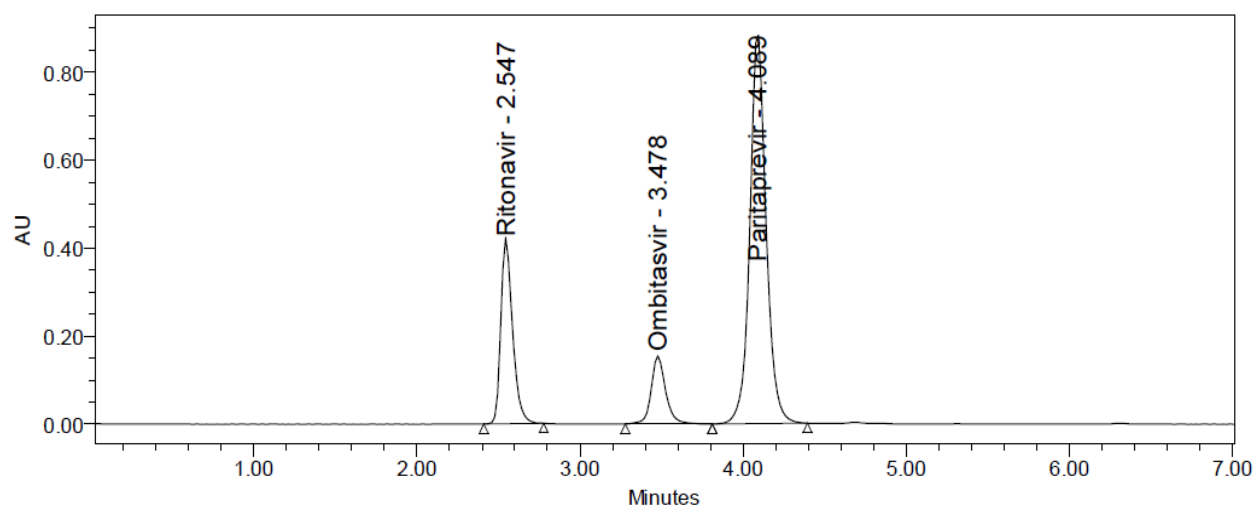

Fig. 19: Chromatogram for accuracy $150 \%-3$

Table 6: Repeatability data for ritonavir, ombitasvir and paritaprevir

\begin{tabular}{llll}
\hline S. No. & Area of ritonavir $\mathbf{n = 6}$ & Area of ombitasvir $\mathbf{n}=\mathbf{6}$ & Area of paritaprevir $\mathbf{n = 6}$ \\
\hline 1. & 853526 & 367465 & 2520129 \\
2. & 863014 & 363235 & 2514709 \\
3. & 862364 & 364103 & 2578495 \\
4. & 851521 & 366719 & 2514428 \\
5. & 856136 & 363687 & 2508742 \\
6. & 852367 & 363628 & 2502558 \\
Mean & 856488 & 364806 & 2523177 \\
SD & 5053.1 & 1807.3 & 27753.0 \\
\%RSD & 0.6 & 0.5 & 1.1 \\
\hline
\end{tabular}

\#n: number of injections ( $\mathrm{n}=6)$, \# \%RSD: percent relative standard deviation

\section{Accuracy}

These results were within the acceptable limit of 98-102. The \% RSD for ritonavir, ombitasvir and paritaprevir were $0.7,1.0$ and 0.6 and it is within the limit of $\leq 2$, hence the pr oposed method was accurate and the results were summarized in table 3, 4 and 5 .

\section{Precision}

\section{Repeatability}

The \% RSD found to be $0.6,0.5$ and 1.1 respectively, the obtained results were within an acceptable limit of $\leq 2$ and hence this $m$ ethod was reproducible and the results were shown in table 6 . 
Table 7: Intermediate precision data for ritonavir, ombitasvir and paritaprevir

\begin{tabular}{llll}
\hline S. No. & Area of ritonavir $\mathbf{n = 6}$ & Area of ombitasvir $\mathbf{n = 6}$ & Area of paritaprevir $\mathbf{n}=\mathbf{6}$ \\
\hline 1. & 848671 & 358194 & 2506847 \\
2. & 857139 & 357744 & 2509322 \\
3. & 847451 & 357290 & 2507333 \\
4. & 848792 & 353484 & 2464440 \\
5. & 852392 & 353117 & 2494836 \\
6. & 850073 & 354121 & 2489685 \\
Mean & 850753 & 355658 & 2495411 \\
SD & 3550.0 & 2323.2 & 17080.7 \\
\%RSD & 0.4 & 0.7 & 0.7 \\
\hline
\end{tabular}

${ }^{\#} \mathrm{n}$ : number of injections $(\mathrm{n}=6)$, \# \%RSD: percent relative standard deviation

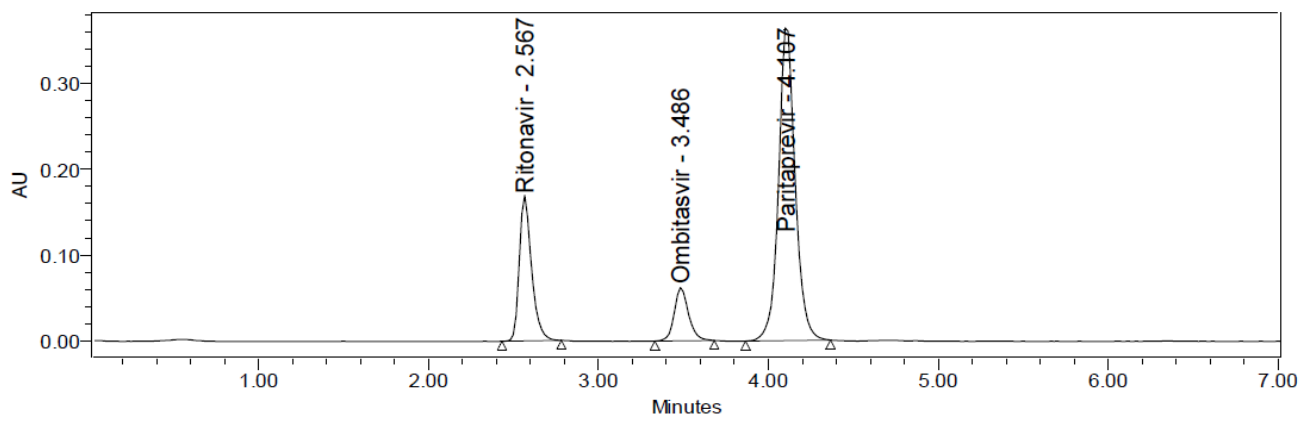

Fig. 20: Chromatogram for method precision-1

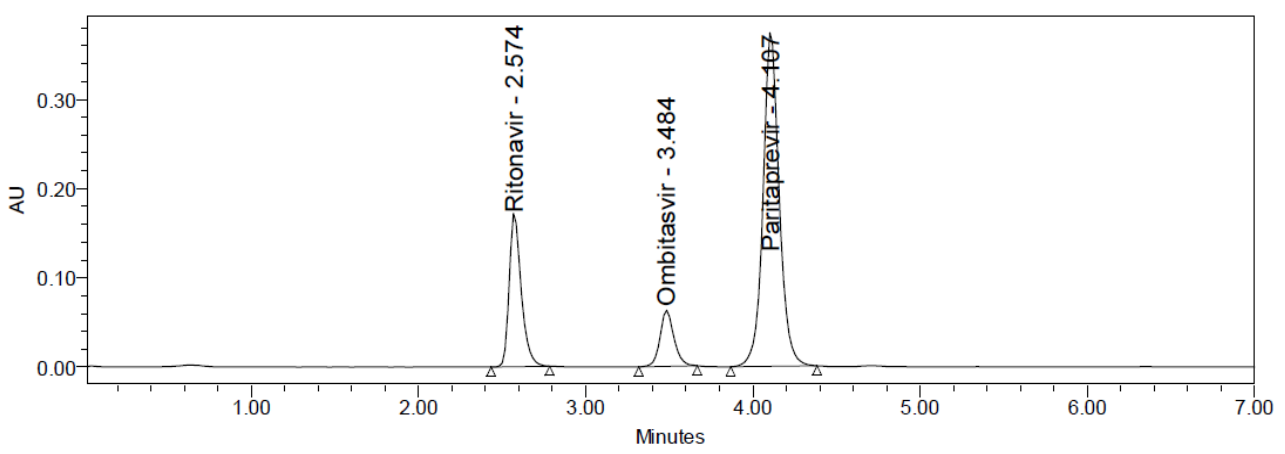

Fig. 21: Chromatogram for method precision-2

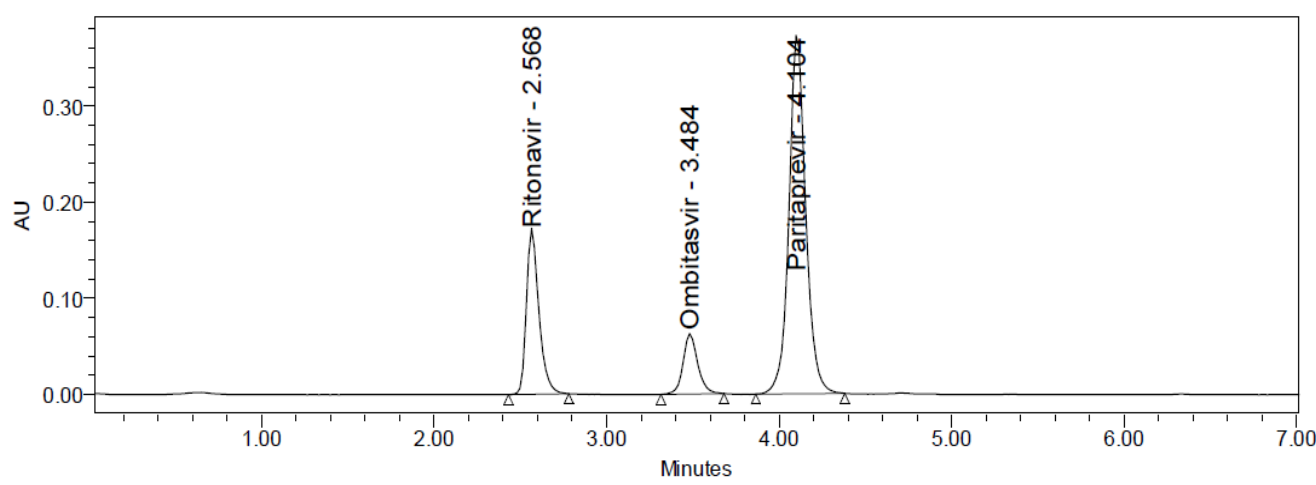

Fig. 22: Chromatogram for method precision-3

\section{Intermediate precision}

The \% RSD for ritonavir, ombitasvir and paritaprevir were found to be $0.4,0.7$ and 0.7 and it was within an acceptable limit of $\leq 2$.
Hence the method is reproducible on different days with different analyst and column. This indicates that the method was precise and the results were as shown in table 7 . 


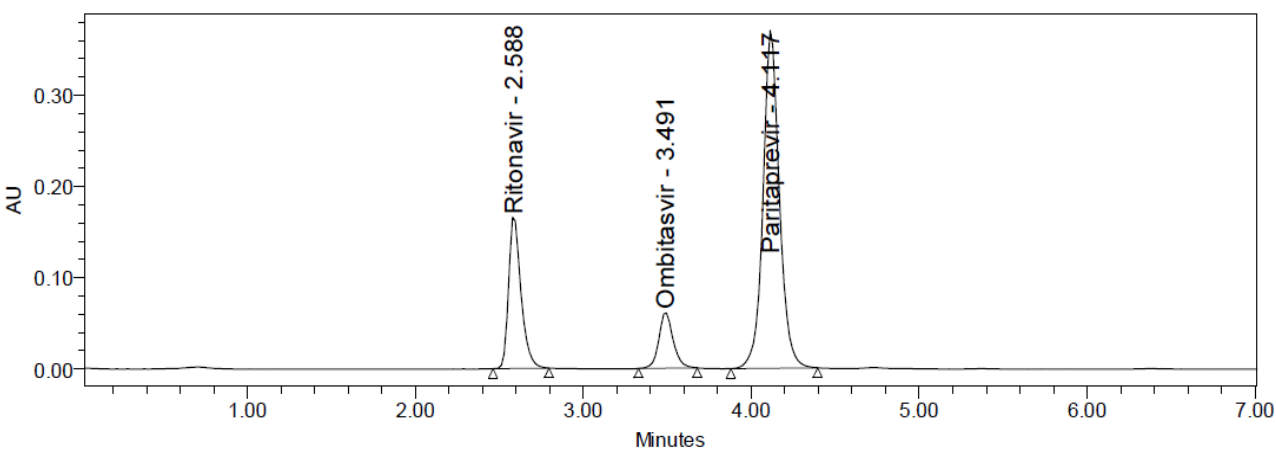

Fig. 23: Chromatogram for method precision-4

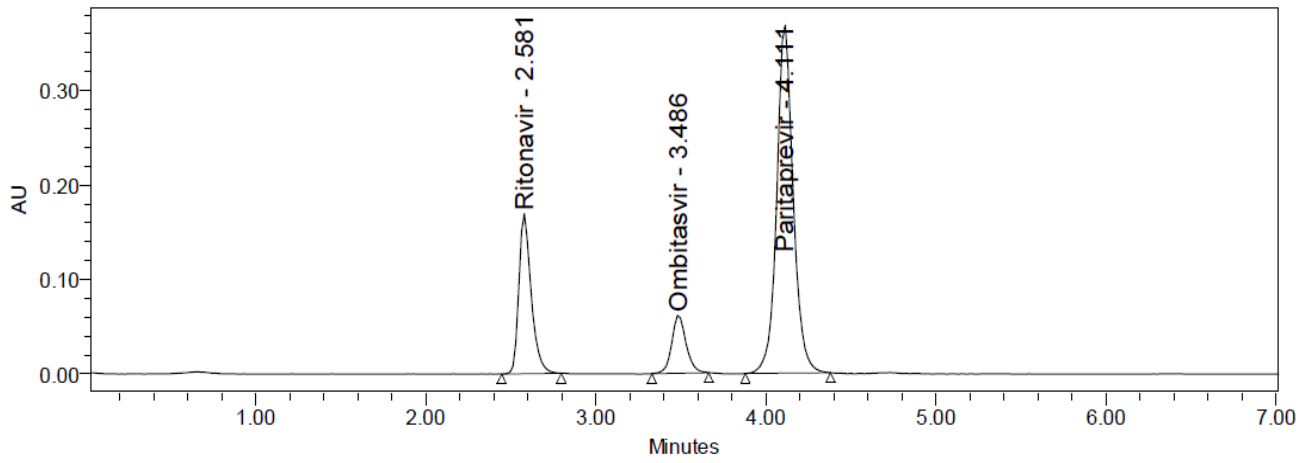

Fig. 24: Chromatogram for method precision-5

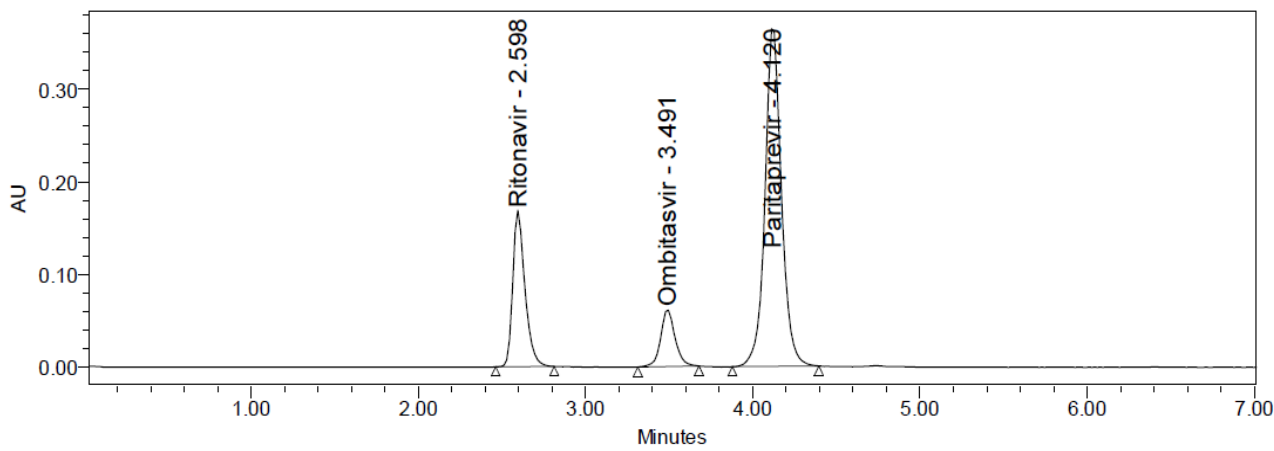

Fig. 25: Chromatogram for method precision-6

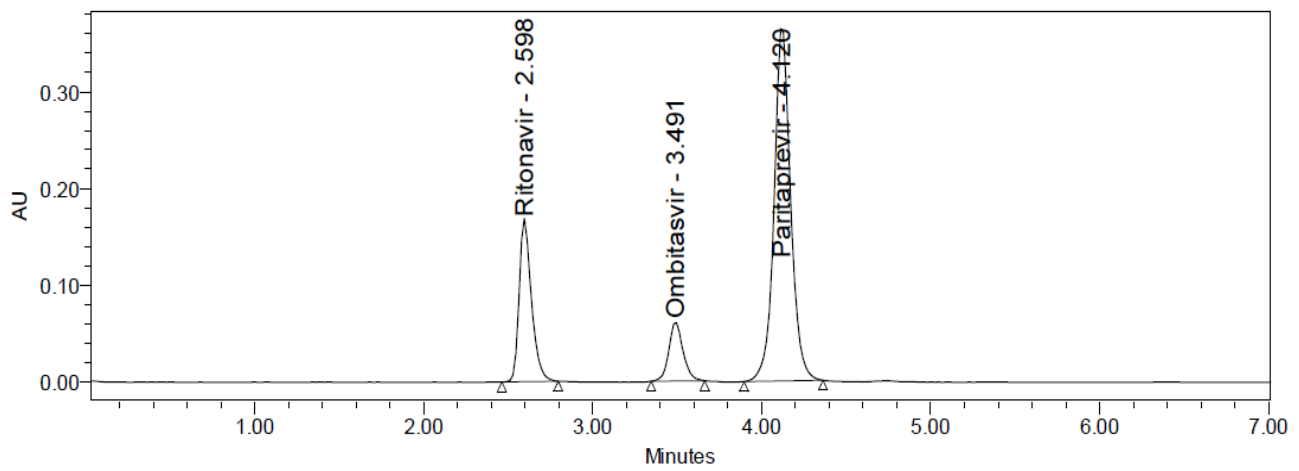

Fig. 26: Chromatogram for intermediate precision-1 


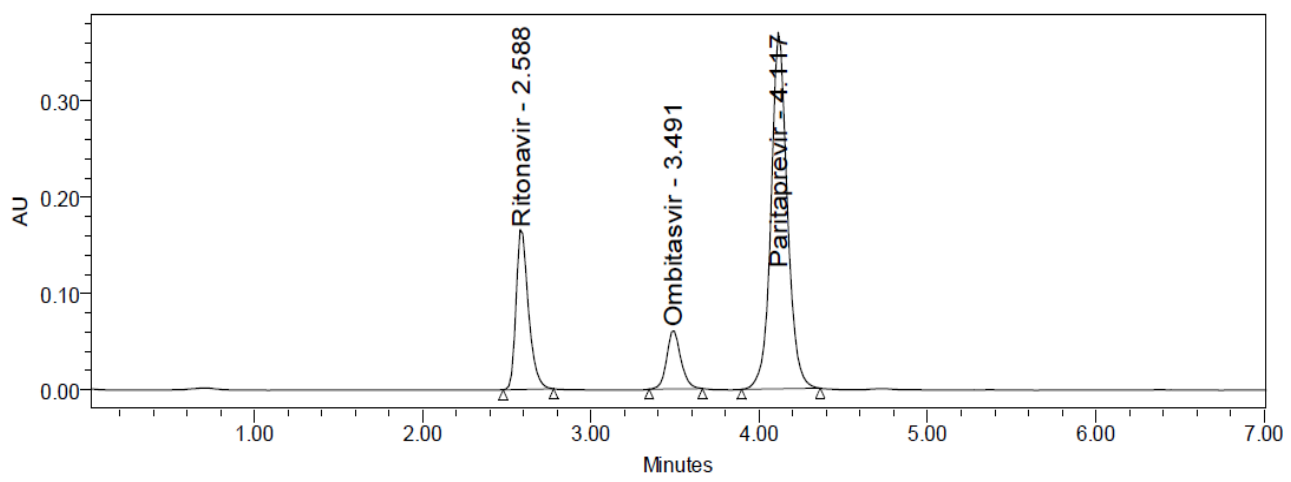

Fig. 27: Chromatogram for intermediate precision-2

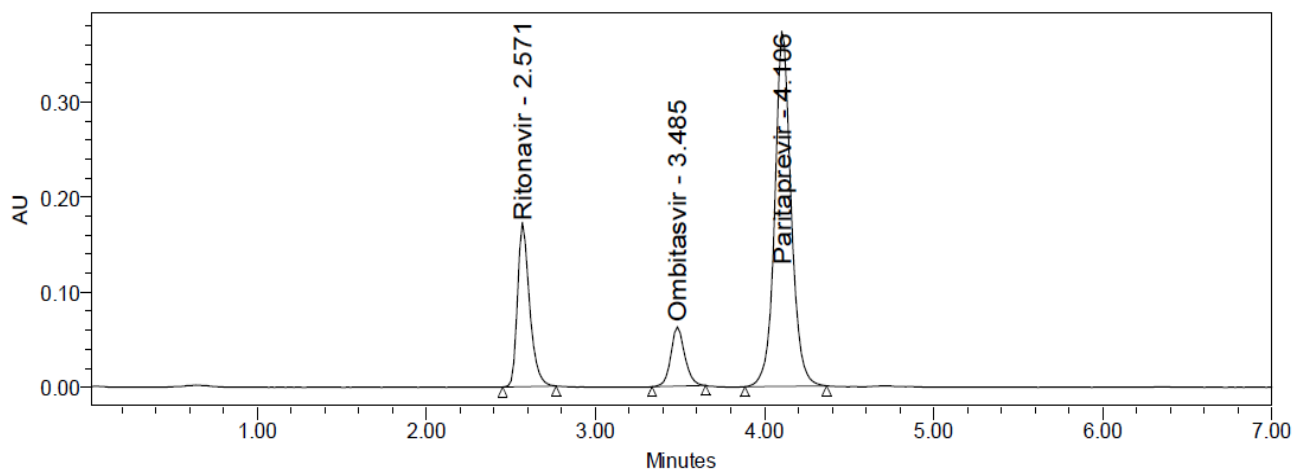

Fig. 28: Chromatogram for intermediate precision-3

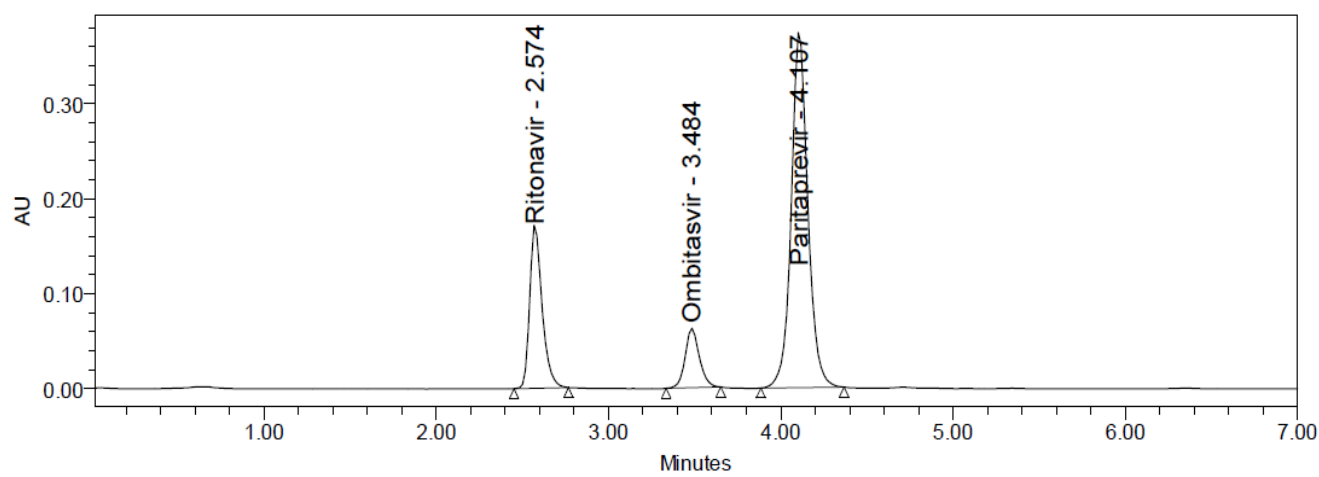

Fig. 29: Chromatogram for intermediate precision-4

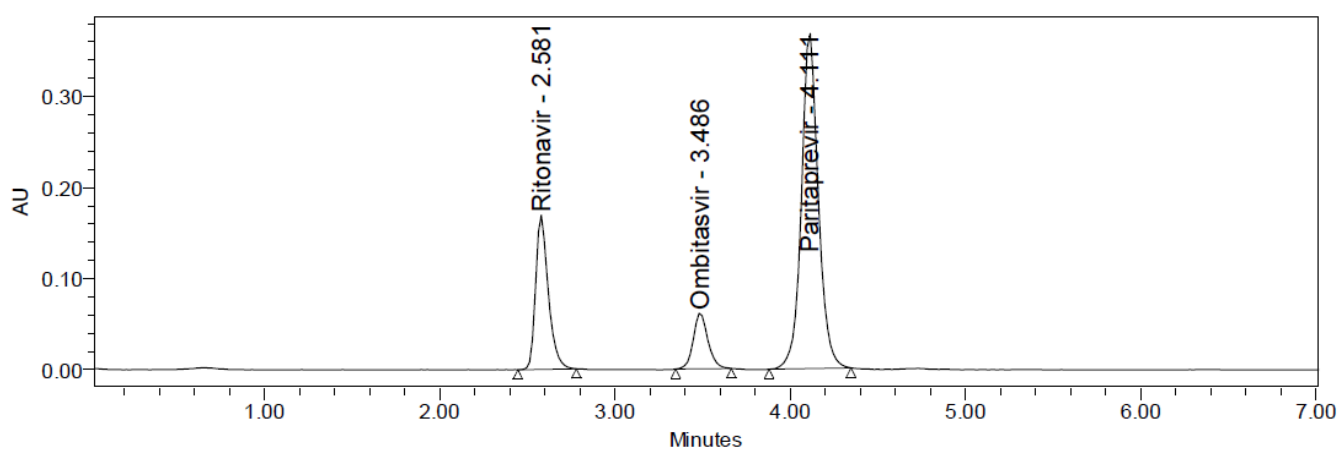

Fig. 30: Chromatogram for intermediate precision-5 


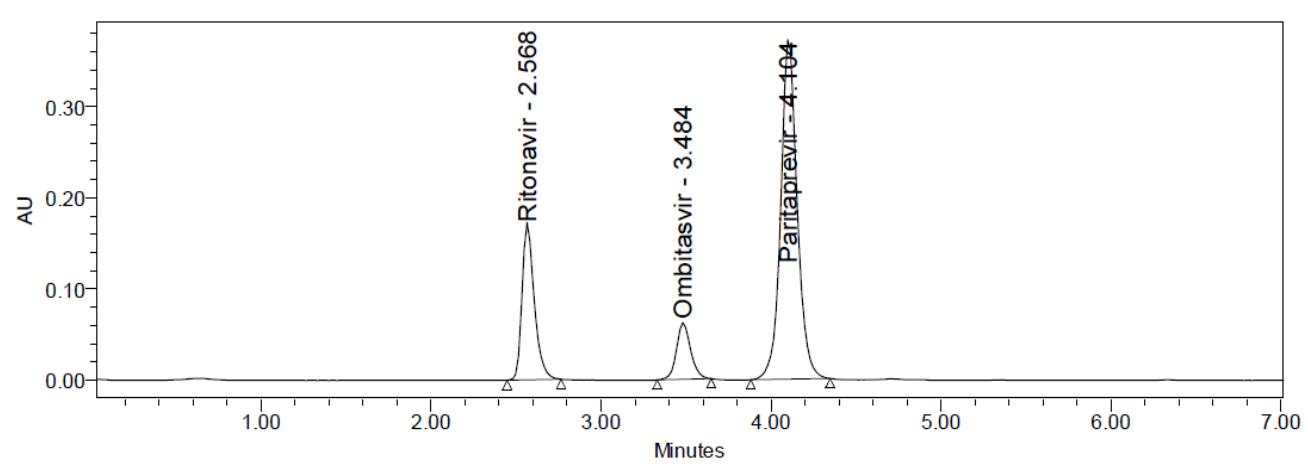

Fig. 31: Chromatogram for intermediate precision-6

\section{LOD and LOQ}

LOD and LOQ for ritonavir, ombitasvir and paritaprevir were 0.02,
0.019 and $0.02 \mu \mathrm{g} / \mathrm{ml}$ and $0.07,0.06$ and $0.07 \mu \mathrm{g} / \mathrm{ml}$ respectively. The lowest value of LOD and LOQ as obtained by the proposed method indicates that the method was sensitive [24].

\section{Table 8: Results of LOD and LOQ}

\begin{tabular}{lll}
\hline Drug & LOD $(\mu \mathrm{g} / \mathrm{ml})$ & LOQ $(\mu \mathrm{g} / \mathrm{ml})$ \\
\hline Ritonavir & $0.02 \mu \mathrm{g} / \mathrm{ml}$ & $0.07 \mu \mathrm{g} / \mathrm{ml}$ \\
Ombitasvir & $0.019 \mu \mathrm{g} / \mathrm{ml}$ & $0.06 \mu \mathrm{g} / \mathrm{ml}$ \\
Paritaprevir & $0.02 \mu \mathrm{g} / \mathrm{ml}$ & $0.07 \mu \mathrm{g} / \mathrm{ml}$ \\
\hline
\end{tabular}

\#LOD: limit of detection, \# LOQ: limit of quantization

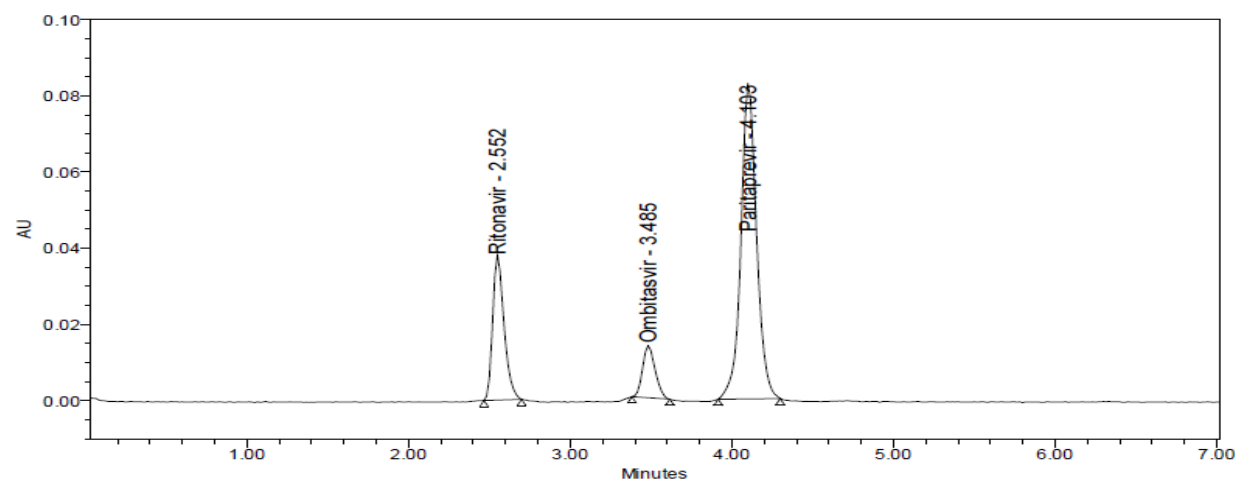

Fig. 32: Chromatogram for LOD

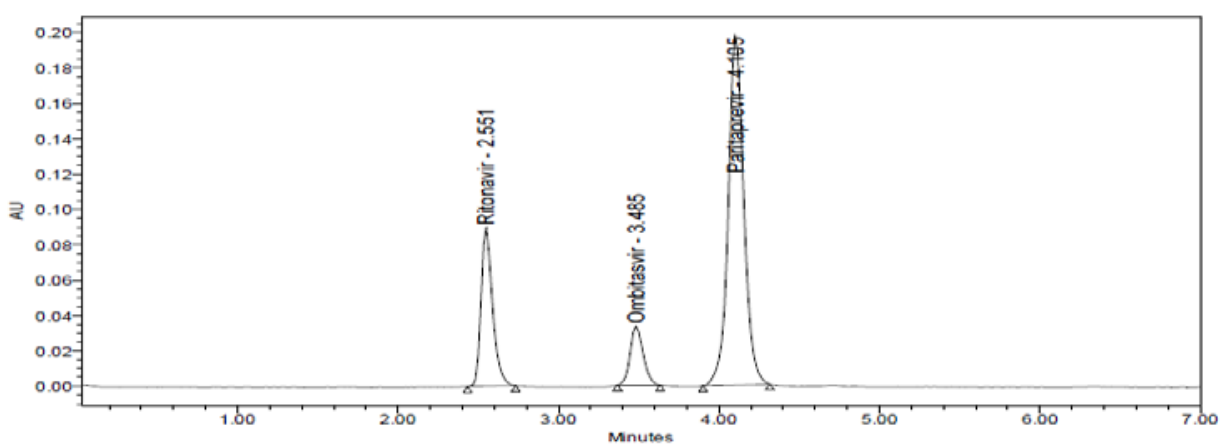

Fig. 33: Chromatogram for LOQ

\section{Degradation studies}

The degradation studies for ritonavir, ombitasvir and paritaprevir were performed by various conditions like acid, alkali, oxidation, thermal photolytic and neutral degradation and their limits like purity angle and purity threshold values were mentioned. It is observed that the purity angle<purity threshold and the results were shown in table 9, 10 and 11 .

\section{Oxidation}

To $1 \mathrm{ml}$ of stock solution of ritonavir, ombitasvir, and paritaprevir, 1 $\mathrm{ml}$ of $20 \%$ hydrogen peroxide was added separately. The solutions were kept for $30 \mathrm{~min}$ at $60{ }^{\circ} \mathrm{C}$. For HPLC study, the resultant solution was diluted to obtain $50 \mu \mathrm{g} / \mathrm{ml}, 12.5 \mu \mathrm{g} / \mathrm{ml}$ and $75 \mu \mathrm{g} / \mathrm{ml}$ solutions and $10 \mu \mathrm{l}$ were injected into the system and the chromatograms were recorded to assess the stability of the sample. 


\section{Acid degradation studies}

$1 \mathrm{ml}$ of $2 \mathrm{~N}$ Hydrochloric acid was added to $1 \mathrm{ml}$ of stock solution of ritonavir, ombitasvir and paritaprevir. Then it was refluxed for 30 $\min$ at $60^{\circ} \mathrm{C}$. The resultant solution was diluted to obtain $50 \mu \mathrm{g} / \mathrm{ml}$, $12.5 \mu \mathrm{g} / \mathrm{ml}$ and $75 \mu \mathrm{g} / \mathrm{ml}$ solutions and $10 \mu \mathrm{l}$ solutions were injected into the system and the chromatograms were recorded to assess the stability of the sample.

\section{Alkali degradation studies}

To $1 \mathrm{ml}$ of stock solution of ritonavir, ombitasvir and paritaprevir, $1 \mathrm{ml}$ of $2 \mathrm{~N}$ sodium hydroxide was added and it was refluxed for $30 \mathrm{~min}$ at $60^{\circ} \mathrm{C}$. The resultant solution was diluted to obtain $50 \mu \mathrm{g} / \mathrm{ml}, 12.5 \mu \mathrm{g} / \mathrm{ml}$ and 75 $\mu \mathrm{g} / \mathrm{ml}$ solutions and $10 \mu \mathrm{l}$ were injected into the system and the chromatograms were recorded to know the stability of the sample.

\section{Dry heat degradation studies}

The standard drug solution was placed in an oven at $105^{\circ} \mathrm{C}$ for $6 \mathrm{~h}$ to study dry heat degradation. For HPLC study, the resultant solutions was diluted to $150 \mu \mathrm{g} / \mathrm{ml}, 12.5 \mu \mathrm{g} / \mathrm{ml}$ and $75 \mu \mathrm{g} / \mathrm{ml}$ solution and 10 $\mu \mathrm{l}$ were injected into the system and the chromatograms were recorded to measure the stability of the sample.

\section{Photo Stability studies}

The photochemical stability of the drug was also studied by exposing the $500 \mu \mathrm{g} / \mathrm{ml}, 125 \mu \mathrm{g} / \mathrm{ml}$ and $750 \mu \mathrm{g} / \mathrm{ml}$ solutions to UV light by keeping the beaker in UV Chamber for 7 days or 200 Watt-hours $/ \mathrm{m}^{2}$ in photostability chamber. For HPLC study, the resultant solution was diluted to obtain $50 \mu \mathrm{g} / \mathrm{ml}, 12.5 \mu \mathrm{g} / \mathrm{ml}$ and $75 \mu \mathrm{g} / \mathrm{ml}$ solutions and $10 \mu \mathrm{l}$ were injected into the system and the chromatograms were recorded in order to the stability of the sample.

\section{Neutral degradation studies}

Stress testing under neutral conditions was studied by refluxing the drug in water for $6 \mathrm{~h}$ at a temperature of $60^{\circ} \mathrm{C}$. For HPLC study, the resultant solution was diluted to $50 \mu \mathrm{g} / \mathrm{ml}, 12.5 \mu \mathrm{g} / \mathrm{ml}$ and $75 \mu \mathrm{g} / \mathrm{ml}$ solutions and $10 \mu \mathrm{l}$ were injected into the system and to assess the stability of the sample, the chromatograms were recorded.

Table 9: Results of forced degradation studies of ritonavir

\begin{tabular}{|c|c|c|c|c|}
\hline S. No. & Degradation condition & \% Drug degraded & Purity angle & Purity threshold \\
\hline 1 & Acid & 4.00 & 0.199 & 0.346 \\
\hline 2 & Alkali & 2.58 & 0.165 & 0.310 \\
\hline 3 & Oxidation & 2.70 & 0.165 & 0.310 \\
\hline 4 & Thermal & 1.91 & 0.184 & 0.316 \\
\hline 5 & UV & 1.28 & 0.195 & 0.311 \\
\hline 6 & Water & 0.26 & 0.165 & 0.310 \\
\hline
\end{tabular}

Table 10: Results of forced degradation studies of ombitasvir?

\begin{tabular}{lllll}
\hline S. No. & Degradation condition & \% Drug degraded & Purity angle & Purity threshold \\
\hline 1 & Acid & 4.12 & 0.209 & 0.361 \\
2 & Alkali & 3.31 & 0.253 & 0.321 \\
3 & Oxidation & 3.26 & 0.253 & 0.321 \\
4 & Thermal & 2.33 & 0.259 & 0.345 \\
5 & UV & 1.87 & 0.175 & 0.327 \\
6 & Water & 0.56 & 0.253 & 0.321 \\
\hline
\end{tabular}

Table 11: Results of forced degradation studies of paritaprevir[?

\begin{tabular}{lllll}
\hline S. No. & Degradation condition & \% Drug degraded & Purity angle & Purity threshold \\
\hline 1 & Acid & 3.97 & 0.103 & 0.303 \\
2 & Alkali & 2.81 & 0.106 & 0.302 \\
3 & Oxidation & 2.86 & 0.106 & 0.302 \\
4 & Thermal & 2.09 & 0.109 & 0.305 \\
5 & UV & 1.41 & 0.104 & 0.305 \\
6 & Water & 0.42 & 0.106 & 0.302 \\
\hline
\end{tabular}

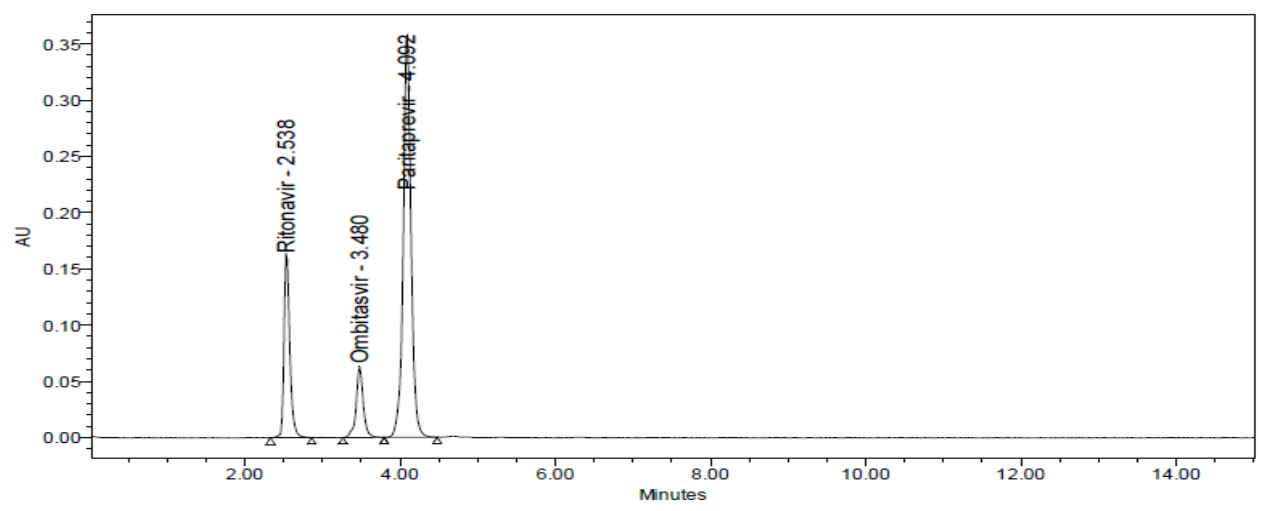

Fig. 34: Chromatogram for acid degradation 


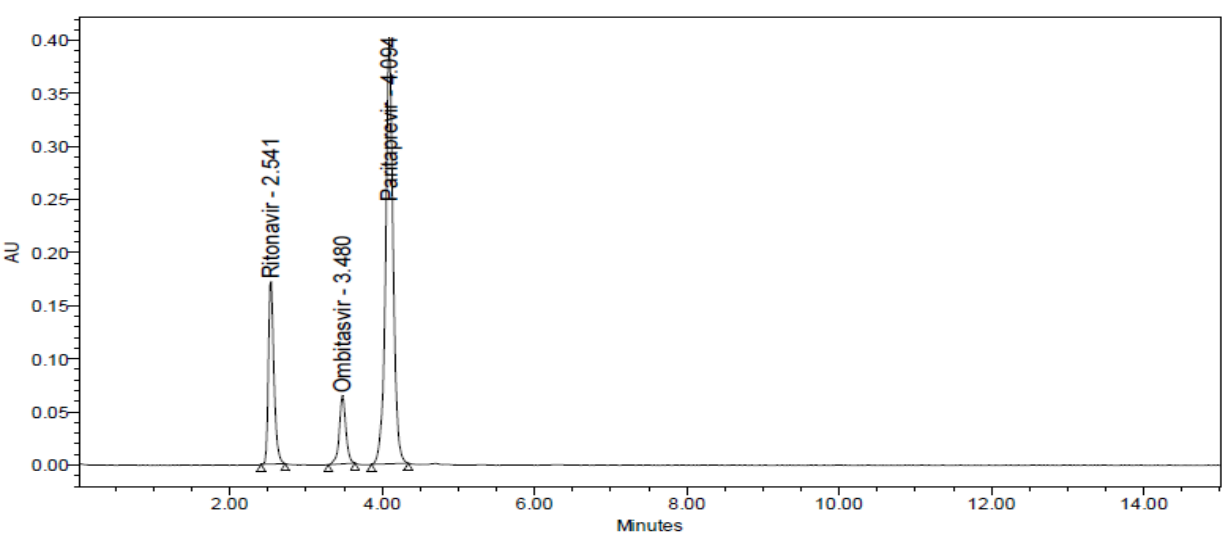

Fig. 35: Chromatogram for base degradation

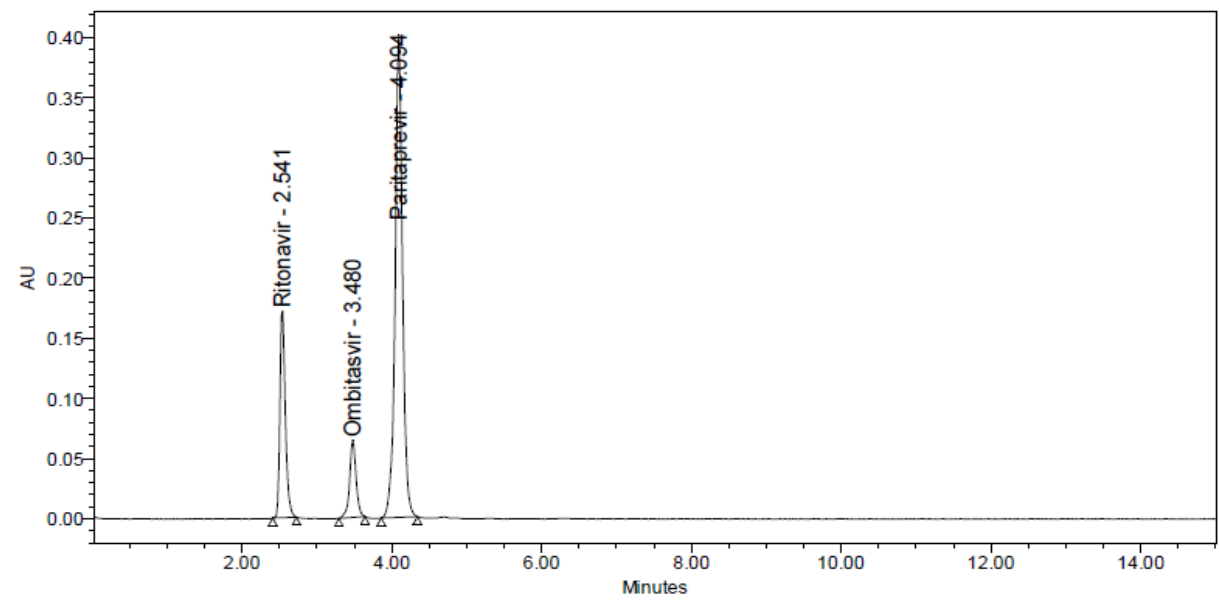

Fig. 36: Chromatogram for peroxide degradation

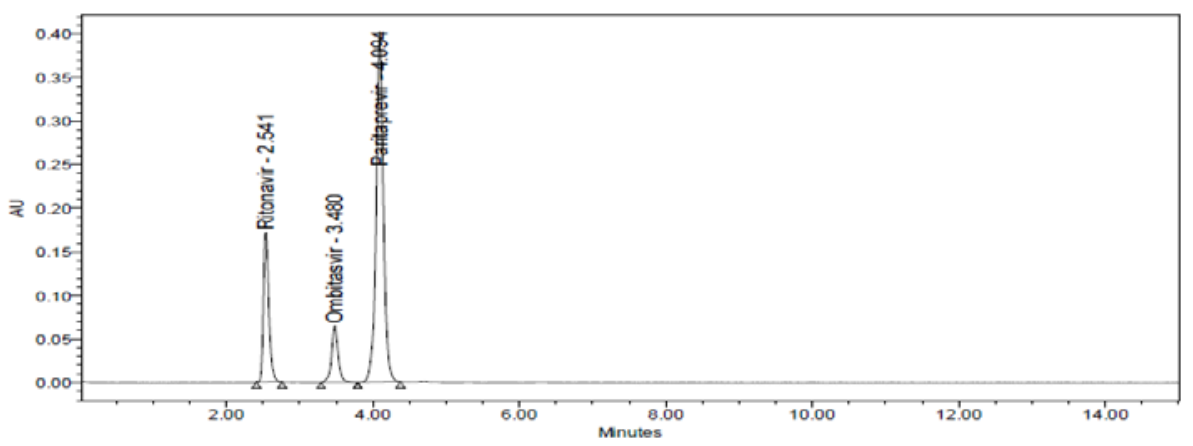

Fig. 37: Chromatogram for thermal degradation

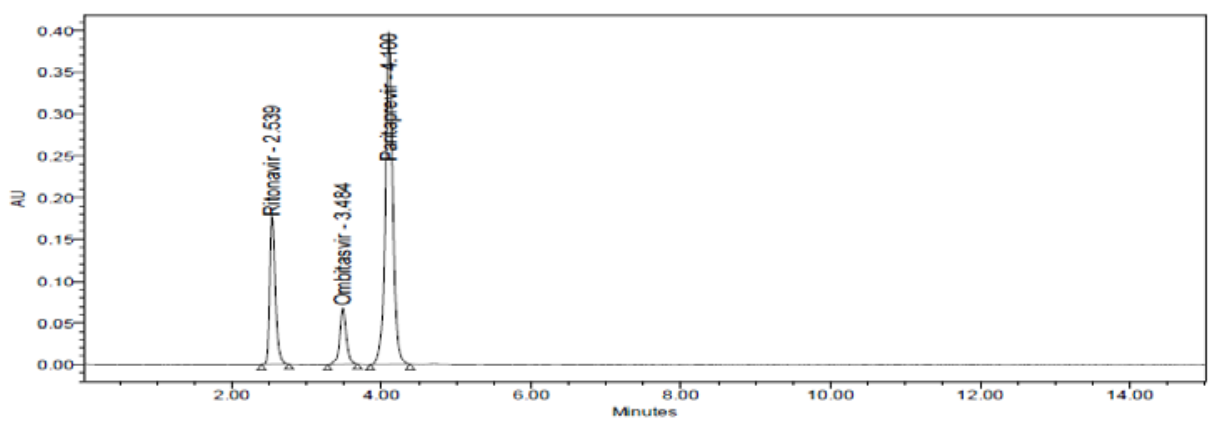

Fig. 38: Chromatogram for photolytic degradation 


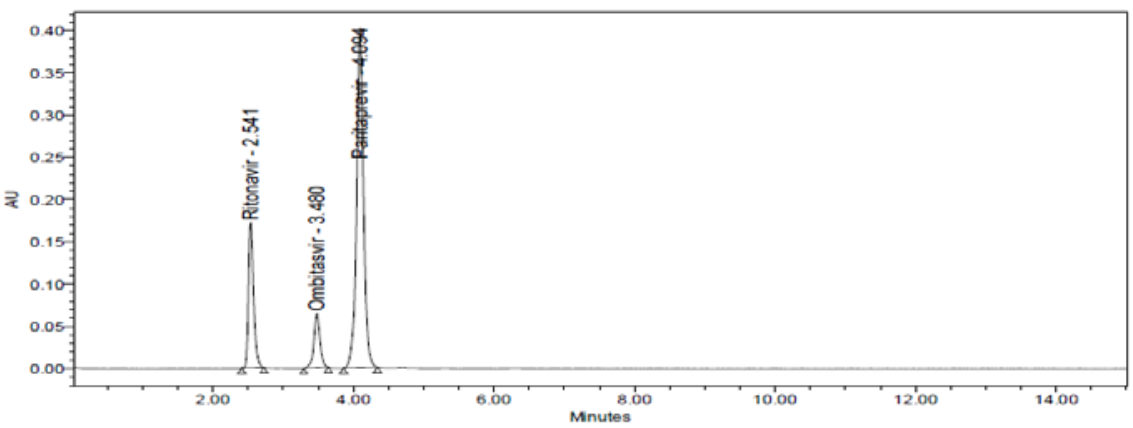

Fig. 39: Chromatogram for hydrolysis degradation

\section{Robustness}

It was observed that there was no marked change in mean Rt and \% RSD was within a limit of $\leq 2$. The tailing factor, resolution factor and no. of theoretical plates were found to be in acceptable limits for ritonavir, ombitasvir and paritaprevir. Hence this method was reliable with variations in the analytical conditions and the results of ritonavir, ombitasvir and paritaprevir were shown in table 12.

Table 12: Results for robustness

\begin{tabular}{|c|c|c|c|c|}
\hline S. No. & Condition & \% RSD of ritonavir & \% RSD of ombitasvir & \% RSD of paritaprevir \\
\hline 1 & Flow rate $(-) 0.9 \mathrm{ml} / \mathrm{min}$ & 1.5 & 0.87 & 1.5 \\
\hline 2 & Flow rate $(+) 1.1 \mathrm{ml} / \mathrm{min}$ & 0.2 & 1.4 & 0.1 \\
\hline 3 & Mobile phase (-) 33B: 67A & 0.7 & 0.79 & 0.6 \\
\hline 4 & Mobile phase (+) 27B: 73A & 1.0 & 1.0 & 1.1 \\
\hline 5 & Temperature $(-) 25^{\circ} \mathrm{C}$ & 1.1 & 1.3 & 1.1 \\
\hline 6 & Temperature $(+) 35^{\circ} \mathrm{C}$ & 1.2 & 0.64 & 0.6 \\
\hline
\end{tabular}

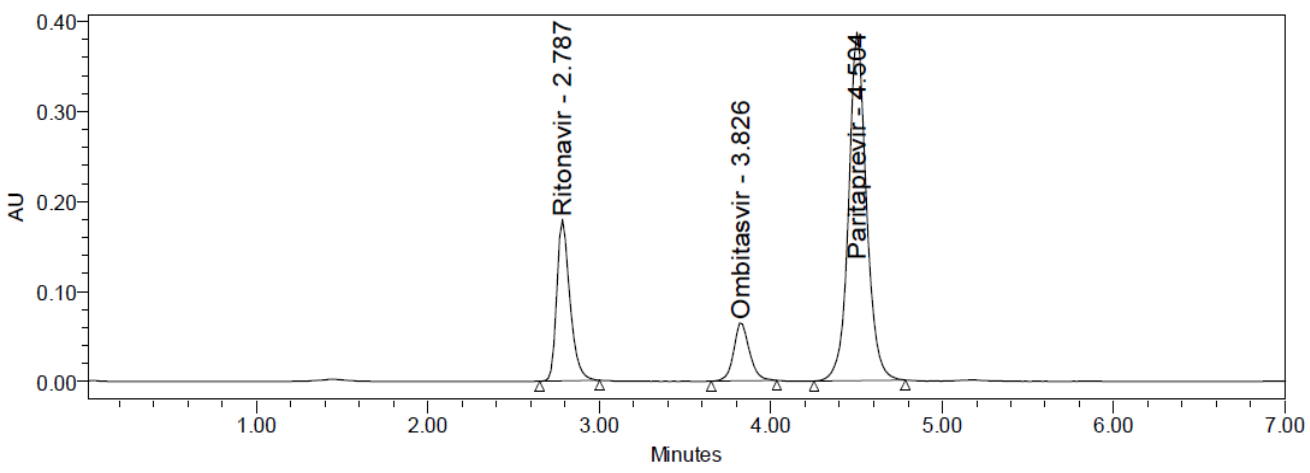

Fig. 40: Chromatogram for flow min

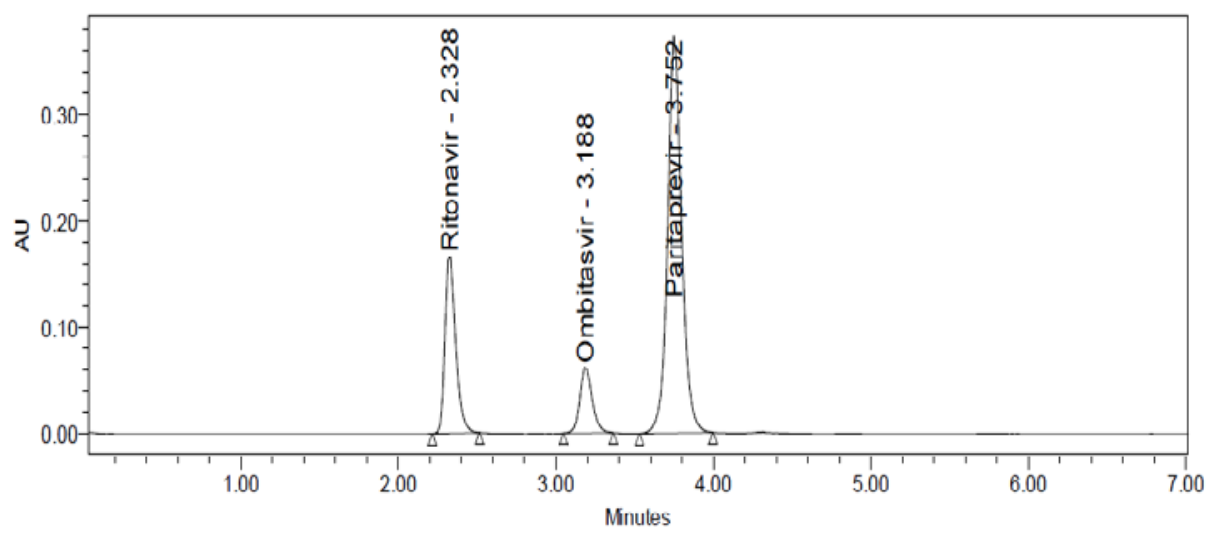

Fig. 41: Chromatogram for flow plus 


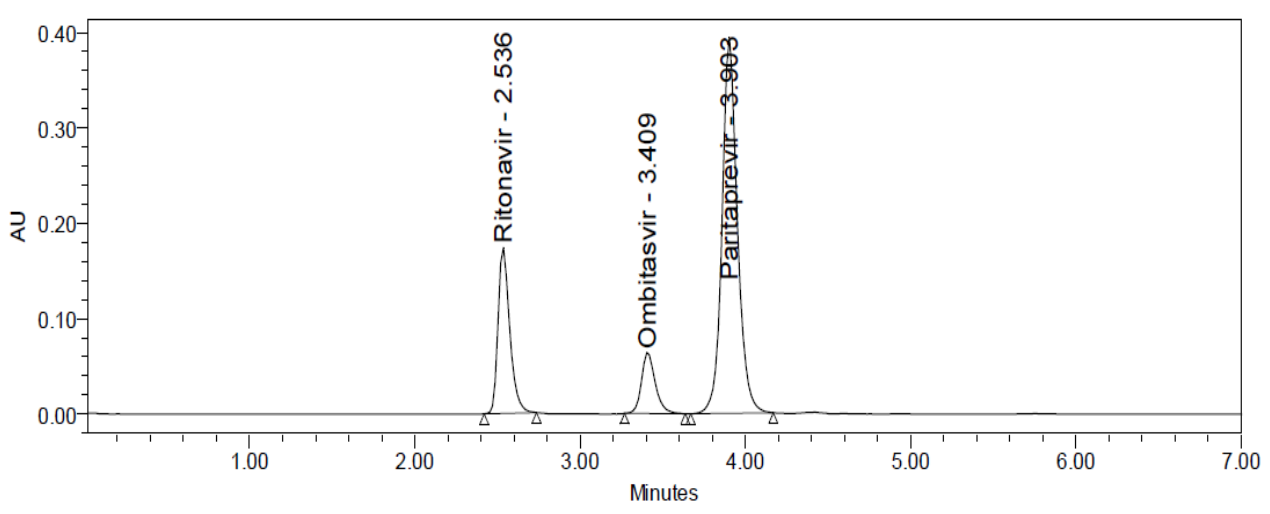

Fig. 42: Chromatogram for organic phase min

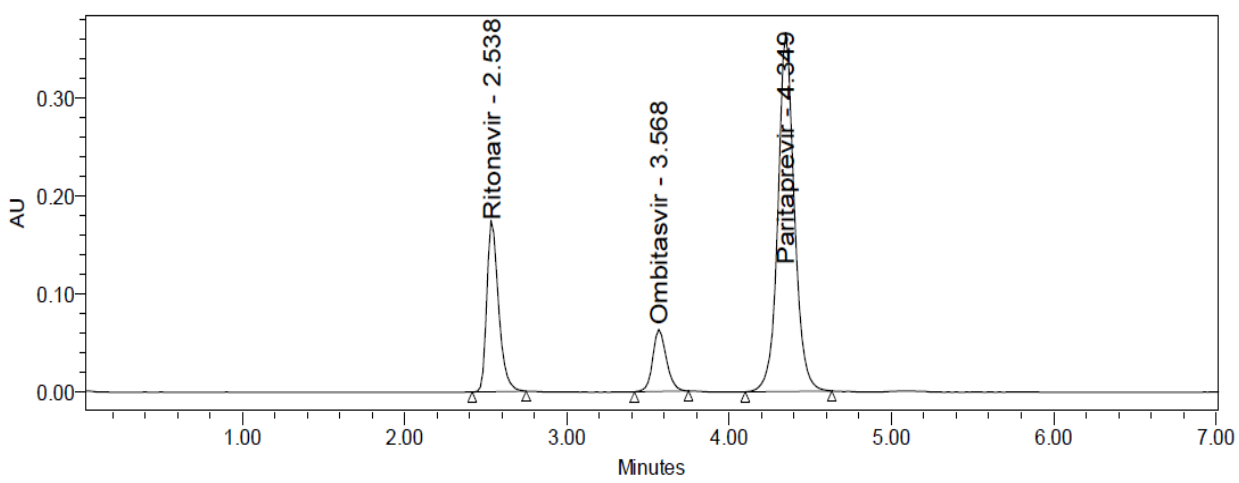

Fig. 43: Chromatogram for organic phase plus

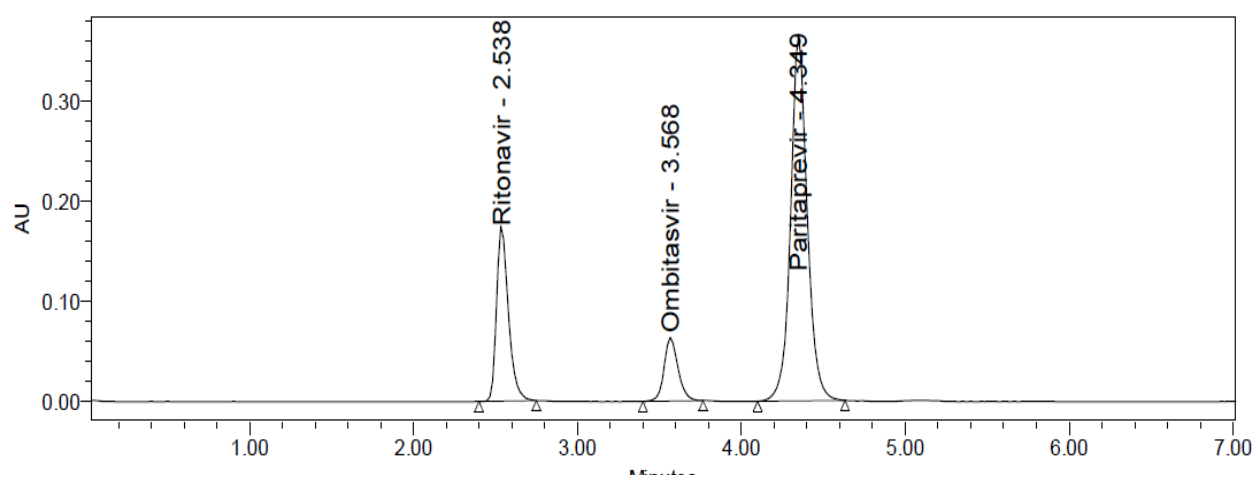

Fig. 44: Chromatogram for temperature min

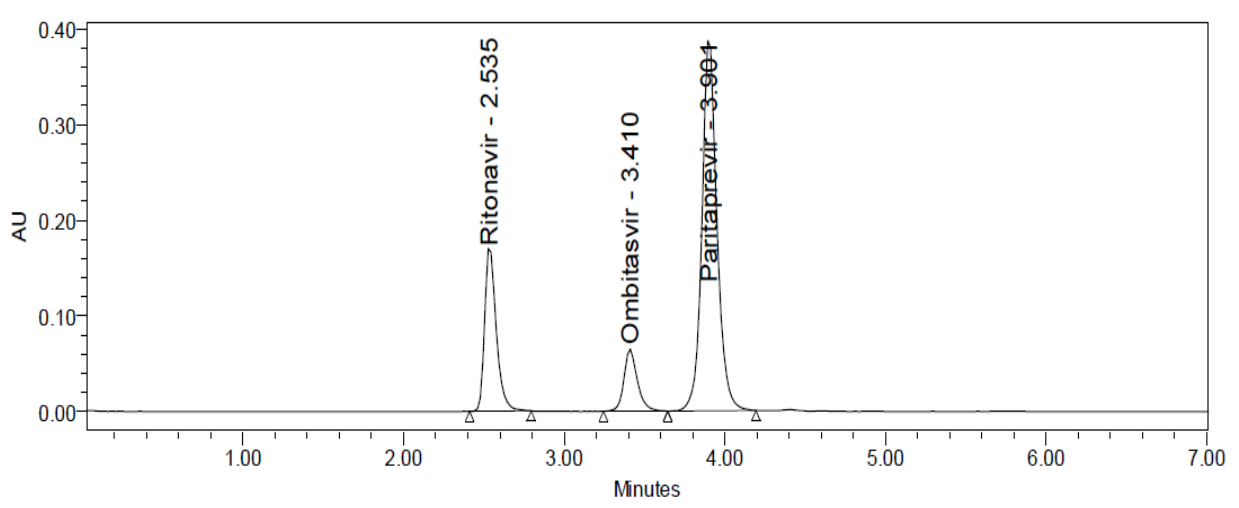

Fig. 45: Chromatogram for temperature plus 


\section{Solution stability}

Sample solutions were analyzed initially for $24 \mathrm{~h}$ at different inter- vals of time at room temperature and the results were recorded. The $\%$ deviation should not be more than $5.0 \%$.

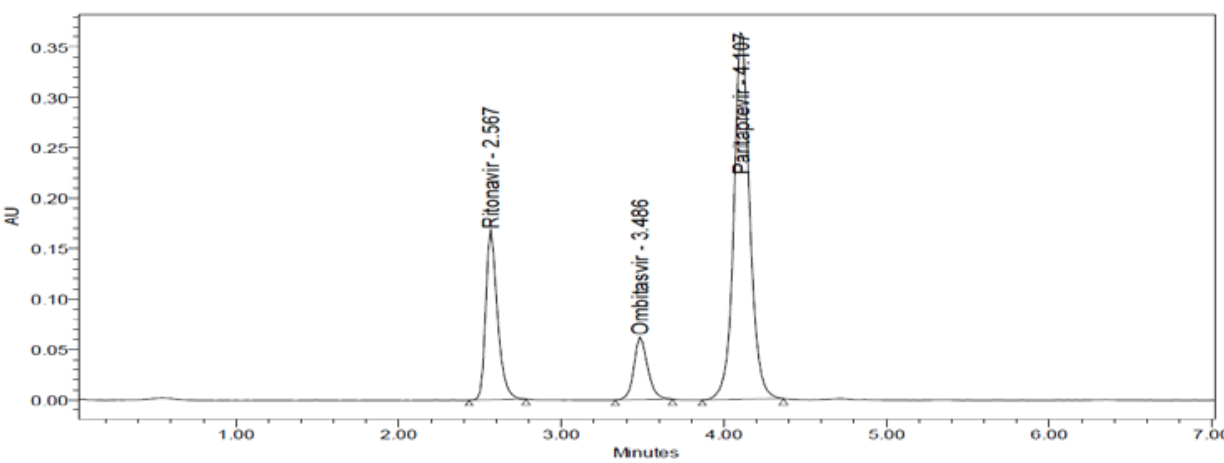

Fig. 46: Chromatogram for stability initial

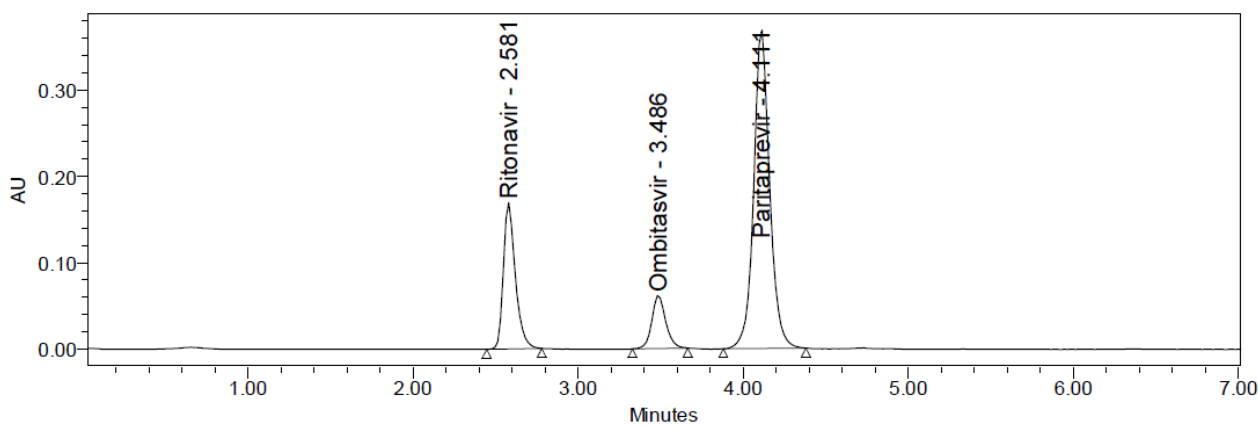

Fig. 47: Chromatogram for stability $24 \mathrm{~h}$

\section{CONCLUSION}

Stability indicating RP-HPLC method was developed and validated for the simultaneous estimation of ritonavir, ombitasvir and paritaprevir in pharmaceutical formulations as per ICH guidelines. The developed method was found to be accurate, precise and reliable with $\%$ RSD less than $2 \%$. Therefore, the developed method was simple, accurate, precise and robust. The present method was found to be stability indicating as the degradation of the drug substance was between 0.25-5 percent. Finally, this method can be used for better analysis of pharmaceutical formulations of ritonavir, ombitasvir and paritaprevir.

\section{AUTHORS CONTRIBUTIONS}

All the author have contributed equally

\section{CONFLICT OF INTERESTS}

Declared none

\section{REFERENCES}

1. Suneetha A, Kathirvel S, Ramachandrika G. A validated RP HPLC method for simultaneous estimation of lopinavir and ritonavir in the combined dosage form. Int J Pharm Sci 2011;3:4951.

2. Chiranjeevi K, Channabasavaraj KP, Lakshminarayana B, Kalyan kumar B. Development and validation of RP-HPLC method for quantitative estimation of ritonavir in bulk and pharmaceutical dosage forms. Int J Pharm Sci Res 2011;2:336-40.

3. Mardia RB, Suhagia BN, PashaTY, Chauhan SP. RP-HPLC method for simultaneous estimation of lopinavir and ritonavir in combined tablet dosage form and in spiked human plasma. Int J Pharm Sci Res 2014;5:3443-54.

4. Sindu Priya D, Gowri Sankar D, Masthanamma SK. Stabilityindicating reversed-phase high-performance liquid chromatography method for the simultaneous estimation of darunavir and ritonavir. Asian J Pharm Clin Res 2016;9:71-6.
5. Dnyaneshwar SP, Manjusha D, Sanjay S, Jyoti MS. Development and validation of RP-HPLC method for the simultaneous estimation of atazanavir sulphate and ritonavir in bulk and formulations. Int J Pharm Sci 2013;5:905-9.

6. De Nicolo A, Simiele M, Calcagno A, Abdi AM, Bonora S, Di Perri $\mathrm{G}$, et al. Intracellular antiviral activity of low-dose ritonavir in boosted protease inhibitor regimens. Antimicrob Agents Chemother 2014;58:4042-7.

7. Sathish Kumar AM, Sandhya Rani B, Mounika N, Mamatha J, Kranthi Kumar J. Validated RP-HPLC method for the simultaneous estimation of atazanavir and ritonavir in pharmaceutical dosage forms. ARC J Pharm Sci 2016;2:21-31.

8. Manoj G, Anil B, Bhanubhai S, Ishwarsinh R, Urvish D, Arpit P, et al. Simultaneous determination of ritonavir and atazanavir in combined tablet dosage form by HPTLC. Asian J Bio Pharm Sci 2012;2:15-9.

9. Monica A, Konerman MD. MSc and Anna, Lok SF, MD hepatitis c treatment and barriers to eradication. Clin Transl Gastroenterol 2016;7:193.

10. Lee SC, Pinsonnault C, Ackad N, Landry P. A189 treatment of chornic hepatitis $C$ genotype 1 in canada, real world experience with ombitasvir/paritaprevir/r and dasabuvir with or without ribavirin. J Canadian Association Gastroenterol 2018;1:329-30.

11. Asselah T, Hezode C, Qaqish RB, ElKhashab M, Hassanein T. Ombitasvir, paritaprevir, and ritonavir plus ribavirin in adults with hepatitis $\mathrm{C}$ virus genotype 4 infection and cirrhosis (AGATE-I) a multicentre, phase 3, randomised open-label trial. Lancet Gastroenterol Hepatol 2016;1:25-35.

12. Nicholas JB, Zameer M, Asmaa G, Mark WS, Nicola AC. Hepatitis C treatment where are we now. Int J Gen Med 2017;10:39-52.

13. Poordad F, Agarwal K, Younes Z, Cohen D, Xie W, Podsadecki T. Low relapse rate leads to high concordance of sustained virologic response (SVR) at $12 \mathrm{w}$ with SVR at $24 \mathrm{w}$ after treatment with ABT-450/ritonavir, ombitasvir, and dasabuvir plus ribavi- 
rin in subjects with chronic hepatitis $C$ virus genotype 1 infection in the AVIATOR study. Clin Infect Dis 2015;60:608-10.

14. Jensen SB, Serre SB, Humes $\quad$ DG, Ramirez S, Li YP, Bukh J, Gottwein JM. Substitutions at NS3 residue 155, 156, or 168 of hepatitis $C$ virus genotypes 2 to 6 induce complex patterns of protease inhibitor resistance. Antimicrob Agents Chemother 2015;59:7426-36.

15. Kranthi Kiran K, Srinivasa Rao A, Gowri Sankar D. Development and validation of new stability indicating RP-HPLC method for the determination of selected combinational antiviral drugs in bulk and pharmaceutical dosage forms. Int J Med Chem Anal 2017;7:63-73.

16. Jahnavi B, Ganapaty S. Stability indicating RP-HPLC method development and validation for the simultaneous determination of ombitasvir, paritaprevir and ritonavir in tablet dosage forms. Asian J Pharm Edu Res 2018;7:90-101.

17. Srinivas B, Yadagiriswamy P. Analytical method validation report for assay of ombitasvir, paritaprevir and ritonavir by RP-HPLC. Int J Anal Bio Chem 2017;7:12-22.

18. Parbati K, Appala Raju N. Development and application of the liquid chromatographic method for simultaneous determina- tion of ombitasvir, paritaprevir and ritonavir in fixed tablet dosage form. Indo Am J Pharm Res 2018;8:1459-67.

19. International conference on harmonization ICH harmonised tripartite guideline Validation of analytical procedures, text and methodology Q2 (R1) ICH, Geneva; 2005.

20. International Conference on Harmonization (ICH), Stability testing of new drug substances and products, Q1A (R2); 2003.

21. International Conference on Harmonization (ICH) Harmonized Tripartite Guidelines, Validation of Analytical Procedures, Text, and Methodology, Q2 (R1), Parent Guidelines on Methodology Dated; 1996. p. 6.

22. The United States Pharmacopoeia 34, the National Formulary 29. Vol. II, III. Rockville MD. US Pharmacopoeial Convention 2011;2445:3782-4608.

23. Rajendra BP, Tushar AD, Vijay RP. Stability indicating HPLC method for dapoxetine $\mathrm{HCl}$ in bulk and in the formulation. Int ] Pharm Pharm Sci 2014;6:687-90.

24. Ravichandran V, Shalini S, Sundram KM, Harish R. Validation of analytical methods-strategies and importance. Int J Pharm Pharm Sci 2010;2:18-22. 